\title{
İslâm Siyaset Tarihinin Meşhur Hatipleri: Dühât-1 Arab Örneği
}

\author{
Melek Yulmaz Gömbeyaz \\ Dr., Kur’an Kursu Öğreticisi, Türkiye Cumhuriyeti Diyanet İşleri Başkanlı̆̆ı (ROR ID: 00pcsg584) \\ Başiskele İlçe Müftülüğ̈̈ \\ PhD., Teacher at Qur'an School, Republic of Turkey, Presidency of Religious Affairs, Muftiship of Başiskele District \\ mygombeyaz@gmail.com \\ ORCID: 0000-0001-5705-8826
}

\section{Famous Orators of Islamic Political History: The Case of Duhāt al-'Arab}

\section{Abstract}

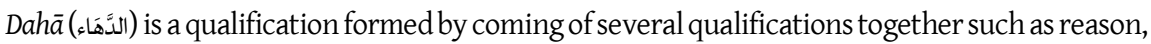
intelligence, wisdom, being good at repartee, ability to find prompt and influential solutions to problems etc.; and dāhi (الداهي) is the person having these specialties at the highest level and becoming distinguished from other people. Duhāt al-'Arab (دُهاة العرب), meaning genius figures of Arabs, are these being famous among Arabs as genius particularly in early Islamic period. This particular expression refers to a specific group with several persons, particularly four ones according to many narrations. These persons are 'Amr b. al-'Ās (d. 43/664), al-Mughïra b. Shu'ba (d. 50/670), Ziyād b. Abih (d. 53/673), and Mu'āwiya b. Abī Sufyān (d. 60/680).

Narrations say that although daha is a common characteristic of these four men, they have their own distinctive qualifications. For instance, 'Amr b. al-'Ās was a genius in solving difficult, problematic and very complicated issues and in intelligence and being good at repartee; al-Mughïra b. Shu'ba was a genius in handling great problems with political solutions; Ziyād b. Abih was a genius in solving each small or big problems even if it requires violence; Mu'āwiya b. Abī Sufyān was a genius in behaving after thinking broadly with patience and soberness. All these figures were also rulers at the highest positions in the government and became prominent with their capacity of using the art of oratory as well as genius. 'Amr b. al-'Ās from Mecca was commissioned in significant official duties during both the Prophet and the Rightly Guided Caliphates and assumed the title of "the Conqueror of Egypt" by virtues of military achievements along with political ones. His political genius clearly appeared with his critical intelligent move that saved Mu'āwiya b. Abī Sufyān from defeat against the Caliph 'Alī b. Abī Ṭālib at the Șiffīn war. Al-Mughïra b. Shu'ba from al-Țā'if, like 'Amr, served several official positions during both the Prophet and the Rightly Guided Caliphates and successfully carried on the governorship of alBașra and al-Kūfa at the period of Mu'āwiya's caliphate. He had very critical roles to have taken on the political scene: $\mathrm{He}$, according to narrations, started the practice of sabb (the cursing of 'Alī b. Abī Țālib) at the jum‘a prayer's sermon, made important contributions to Mu'āwiya in

İntihal Taraması/Plagiarism Detection: Bu makale intihal taramasından geçirildi/This paper was checked for plagiarism Geliş/Received: 14 Haziran/June 2020|Kabul/Accepted: 29 Ağustos/August 2020 | Yayın/Published: 20 Eylül/September 2020 Atıf/Cite as: Melek Yılmaz Gömbeyaz, "İslâm Siyaset Tarihinin Meşhur Hatipleri: Dühât-1 Arab Örneği = Famous Orators of Islamic Political History: The Case of Duhāt al-'Arab", Eskiyeni 41 (Eylül/September 2020), 731-756.

https://doi.org/10.37697/eskiyeni.752631

Copyright @ @ Anadolu İlahiyat Akademisi/Anatolian Theological Academy, 06050, Ankara, Turkey | www.anilakademi.com CC BY-NC 4.0 | This paper is licensed under a Creative Commons Attribution-NonCommercial License 
bringing Ziyād $\mathrm{b}$. Abih who was his intimidating enemy into the fold, and finally, according to narrations, imbued Mu'āwiya with appointing his son Yazìd to the throne after him, accordingly became influential on the transformation of the governmental system from caliphate to dynasty. Ziyād $b$. Abih, another one from al-Tāàif, managed to distinguish with his educational abilities and knowledge in accountancy in his early ages, as well as the high capacity of intelligence and oratory although he, as a son of slave parents, was at a highly disadvantaged position in terms of genealogy that was regarded as a critical reference in the Arab society. After many official duties, he became a very powerful governor that was seen as the most strong castle of Mu'āwiya and the Umayyads. His famous sermon known as "Batrā" was just as very impressives as his activities. Mu'āwiya b. Abī Sufyān, the only caliph from these four genius figures, firstly formed a strong team when he became a caliph and by doing this, he prefers the persons known as duhāt al-'Arab. He found the opportunity to work together with these mentioned geniuses and took the advantage of them.

The present article tries to examine the competence of these four figures in the art of oratory by studying the literary samples narrated about them such as sermons, apothegms, letters etc.; to point out their both personal and political backgrounds as a main factor of their genious and capacity of oratory by making connections between them; and to highlight that even if these persons called Arab genious have different characteristics, the significant common speciality of them is the high power of oratory.

\section{Keywords}

Islamic History, Umayyads, 'Amr b. al-'Ās, al-Mughīra b. Shu'ba, Ziyād b. Abih, Mu'āwiya b. Abī Sufyān, duhāt al-'Arab, Oratory

\section{İslâm Siyaset Tarihinin Meşhur Hatipleri: Dühât-1 Arab Örneği}

\section{Öz}

Akıl, zekâ, idrâk, basiret, ileri görüşlülük, hazır cevaplılık, problemlere çabuk ve etkili çözüm bulabilme gibi özelliklerin bir araya gelmesiyle oluşan özelliğe dehâ; tüm bu vasıfları ileri derecede bünyesinde barındıran, bu yönleriyle diğer insanlardan ayrılan kimselere de dâhi denmiştir. Dühât- $ı$ Arap ise, Arapların dâhileri, Araplar arasında dâhi olarak meşhur olmuş kişiler, Arap dâhiler gibi anlamlara gelmektedir. Özel bir kullanımı olan bu ifade, birkaç kişiden, rivayetlerin çoğunluğuna göre dört isimden oluşan özel bir grubu temsil etmektedir. Dühât-1 Arap dendiğinde akla gelen bu isimler ise, birçok kaynağa göre, Amr b. el-Âs (öl. 43/664), Mugîre b. Şu'be (öl. 50/670), Ziyâd b. Ebîh (öl. 53/673) ve Muâviye b. Ebî Süfyân'dır (öl. 60/680).

Rivayetler, bu dört ismin ortak özelliği olan dehâ bakımından benzerliklerinin yanı sıra bazı farklılıklara sahip olduklarını belirtir. Söz konusu rivayetlere göre Amr b. el-Âs, zor ve illetli meseleleri, içinden çıkılamayan karmaşık problemleri çözmede, zekîlik ve hazır cevaplılıkta; Mugîre b. Şu'be keskin bir zekâ ve hazır cevaplllı ile çözülmesi güç, büyük problemleri politik yollardan halletmede; Ziyâd b. Ebih küçük-büyük her işi, gerekirse şiddet karıştırmak suretiyle çözmede; Muâviye b. Ebî Süfyân ise sabır, temkin, hilm ve teenni ile işleri enine boyuna düşünüp tartarak hareket etmede dâhi idi. Bu dört ismin hepsi de devlet kademelerinde yükselerek üst düzey idarecilik yapmış ve yönetimleri süresince dehâlarının yanı sıra hitabet kabiliyetlerini de gösterecek şekilde sivrilmişlerdir. Bunlardan Mekkeli Amr b. el-Âs, hem Hz. Peygamber hem de Râşid Halifeler döneminde önemli resmî görevlerde bulunmuş; siyaset sahası dışında askerî alanlarda da elde ettiği başarılarla "Mısır fâtihi" ünvanını almıştı. Onun siyasî dehâsı ise tam anlamıyla Hz. Ali karşısında Sıffin Savaşı sürecinde Muâviye'yi dâhiyâne bir hamle ile mutlak yenilgiden kurtarması ile kendini göstermişti. Taifli Mugîre b. Şu'be de Amr gibi hem Hz. 
Peygamber hem de Hulefâ-i Râşidîn dönemlerinde çeşitli mevkilerde devlet hizmetinde bulunmuş; Muâviye'nin iktidarı döneminde Basra ve Kûfe valilikleri görevlerini başarıyla yürütmüştür. Onun siyâset sahnesindeki belki en önemli rollerinin ilki, rivayetlere göre, Emevî Devleti'nde hutbelerde sebb (Hz. Ali'ye sövülmesi/Hz. Ali yerilirken Hz. Osman'ın övülmesi) uygulamasını başlatmasıdır. İkincisi ise, Muâviye'nin uykularını kaçıran düşmanı Ziyâd b. Ebîh'i ona kazandırmadaki katkılarıdır. Üçüncüsü ise, yine rivayetlere göre, Muâviye'ye oğlu Yezid’i kendine veliaht tayin etmesi gerektiğini telkin etmesi ve böylece devlet yönetiminin hanedanlık sistemine dönüşmesinde etkili olmasıdır. Bir diğer Taifli dâhi ve hatip olan Ziyâd ise neseb üstünlüklerinin yarıştırıldığı bir Arap toplumunda, hem babası (köle) hem de annesi (cariye) yönünden hiçbir iddiası olmadığı halde, okur-yazarlı̆̆ı, hesap-kitap işlerinde henüz çocukken aldığı eğitimin yanı sıra dehâ derecesindeki aklı ve hitabet kabiliyeti gibi özellikleri nedeniyle kendini göstermeyi başarmıştı. Hulefâ-i Râşidîn dönemi boyunca hemen her işte istimal edilmiş, son olarak da valilikle görevlendirilmiştir. Muâviye döneminde hem Muâviye'nin hem de Emevî devletinin adeta en sağlam kalesi olmuştu. Onun Betrâ adıyla kaydedilen hutbesi en az uygulamaları kadar meşhur olmuştur. İçlerinde tek halife sıfatına sahip olan Muâviye ise halife olur olmaz işe sağlam bir kadro oluşturarak başlamış; bu doğrultuda ise ilk tercih ettiği isimler dühât-1 Arap olmuştur. O, bu dâhilerin her biriyle çalışma firsatı bulmuş; hizmetlerinden büyük fayda görmüştür.

Bu çalışma Arap Dâhileri olarak anılan bu dört ismin özellikle hitabetleri ile alakalı olarak nakledilen hutbe, vecize, mektup gibi edebî ürünler üzerinden onların hitabet noktasındaki yetkinliklerini ortaya koymaya çalışmakta; gerek dehalarının gerekse de hitabetlerinin geri planında kişisel ve siyasi hayatlarındaki yaşadıklarının olduğunu göstermek üzere irtibatlar kurmakta ve birçok yönden farklılıkları bulunsa da Arap Dâhileri olarak isimlendirilen bu dört ismin en belirgin ortak özelliklerinden birinin yüksek hitabet gücü olduğuna dikkat çekmektedir.

\section{Anahtar Kelimeler}

İslam Tarihi, Emeviler, Amr b. el-Âs, Mugîre b. Şu'be, Ziyâd b. Ebîh, Muâviye b. Ebî Süfyân, Dühât-i Arab, Hitabet

\section{Giriş: Dühât-1 Arab: Tanımı ve Mahiyeti}

Dühât-1 Arab (Arabın dâhileri) ifadesini izaha geçmeden evvel, "dühât” kelimesinin türemiş olduğu "dehâ" köküne kısaca değinmek gerekir. Dehâ sözlükte, zeki, ileri görüşlü, anlayış ve kavrayışı kuvvetli, mahir, gözü açık, hazır cevap gibi manaları ihtiva etmekte olup, ${ }^{1}$ bir insanı diğerlerinden ayıran en önemli özelliklerden biridir. Böyle birçok hasletin bir insanda toplanması ve bu hasletlerin aynı zamanda hayata aktarılmasını içeren ${ }^{2}$ dehâ vasfı, doğuştan gelen faktörlerin yanı sıra, yaşanılan ve tecrübe edilen çevrenin de bir ürünüdür. ${ }^{3}$ Bu bağlamda Dühât-1 Arab ifadesi, yukarıda işaret edilen özellikleri ileri derecede bünyesinde barındıran ve bu yönleriyle diğer insanlardan ayrılmak suretiyle sembolleşen isimleri temsilen bir grup insana hasrolmuş, özel bir tabirdir. Başta siyaset olmak üzere pek çok alandaki zekâ ve kabiliyet

1 İbn Manzûr, Lisânü'l-Arab (Beyrut: Dâru Sadır, ts.), 14/275-276.

2 İrfan Aycan, Saltanata Giden Yolda Muaviye Bin Ebî Süfyan (Ankara: Ankara Okulu Yayınları, 2 bs., 2001), 48.

3 Dehânın tanımı ve mahiyeti konusunda bk. Âdem Apak, İslâm Siyaset Geleneğinde Amr b. el-Âs (Ankara: Ankara Okulu Yayınları, 2001), 206-208. 
üstünlüklerine binaen Dühât-1 Arab olarak anılan bu grubun sayısı hakkında farklı rivayetler bulunsa da ${ }^{4}$ bunların çoğunluğu, çalışmamızın da konusu olan dört kişi üzerinde birleşmektedir. Bunlar, Amr b. el-Âs (öl. 43/664), Mugîre b. Şu'be (öl. 50/670), Ziyâd b. Ebîh (öl. 53/673) ve Muâviye b. Ebî Süfyân'dır (öl. 60/680). Kaynaklarda onların dehasına işaret eden rivayetlerin fazlalığı nedeniyle bunların tamamına değinmek mümkün olmayacağından, belli başlı olanları tercih etmek suretiyle konuyu ele almak uygun olacaktır:

"Bu ümmetin dört kadısı, Ömer, Ali, Zeyd b. Sâbit ve Ebû Mûsâ el-Eş'arî; dört dehâss ise Amr b. el-Âs, Muâviye b. Ebî Süfyân, Mugîre b. Şu'be ve Ziyâd b. Ebîh'tir". ${ }^{5}$

"Meşhûr dört Arap dâhisi içinde Amr, zor ve illetli meseleleri çözüme kavuşturan; Muâviye, sabır, teenni ve temkin ile hareket eden; Ziyâd, küçük-büyük her işi halledebilen; Mugîre, keskin bir zekâ ve doğuştan hazır cevap kabiliyeti olan kişilerdir". 6

Bir başka rivayette, Muâviye b. Ebî Süfyân'ın Amr b. el-Âs'a "dehâ kimdir" diye sorması üzerine Amr'ın, kendisinin de aralarında olduğu dört isme işaret ederek: "Sen, acele davranmayıp temkinli olmada, ben zekîlik ve hazır cevaplılıkta, Mugîre çözülmesi güç, karmaşık işlerde, Ziyâd ise büyük-küçük her işte (öyleyiz)" demek suretiyle her birinin öne çıkan dehâlık vasfına dikkat çektiği görülür.?

Yine, bir yandan dâhileri sayarken öte yandan dehâ lafzının mahiyetine işaret eden bir diğer rivayete göre, dört Arap dehasından Muâviye, teenni ile davranmada ve hilmde; Amr, içinden çıkılamayan karmaşık problemlerde; Mugîre, büyük ve bariz problemlerde; Ziyad da büyük-küçük her meselede dâhidir. ${ }^{8}$ Muâviye, işleri enine boyuna düşünüp tartabilen; Amr, hemen zekice cevaplar verebilen; Mugîre, problemleri politik yoldan halledebilen; Ziyad ise tüm meseleleri, icabında şiddet de karıştırmak suretiyle çözebilen insanlardır ${ }^{9}$ şeklindeki rivayet de bu nevi örneklerdendir.

Şecâat ve mekîde (kurnazlık ve hile) bakımından kuvvetlii, ${ }^{10}$ siyaset ve kiyaset (akıllılık, farkındalık) yönünden müstesna olan bu dâhiler, ${ }^{11}$ Arap dehâları yani

4 Ahmet Önkal, “Dühât-1 Arab”, Türkiye Diyanet Vakfi İslâm Ansiklopedisi (İstanbul: TDV Yayınları, 1994), 10/18.

5 İbn Sa'd, et-Tabakâtü'l-kübrâ (Beyrut: Dâru Sâdır, ts), 2/351; İbn Asâkir, Ebü'l-Kâsım, Târîhu medîneti Dtmaşk, thk. Muhibbüddin Ebi Said Ömer b. Garame el-Amri (Beyrut: Dâru'l-Fikr, 1995), 19/182; Süyûtî, Târîhu'l-Hulefâ (Kahire: el-Mektebetü't-Ticareti'l-Kübra, 4. Basim, 1969), 231.

6 İbn Abdülber en-Nemerî, el-İstîâb fi márifetil-ashâb, thk. Ali Muhammed el-Bicâvî (Kahire, Dâru Nehdati Mısr, ts.), 4/1446; ibn Asâkir, Târîhu medîneti Dımaşk, 19/182; Süyûtî, Târîhu'l-Hulefâ, 231.

7 Belâzürî, Ensâbü'l-eşrâf, thk. Süheyl Zekkar - Riyaz Zirikli (Beyrut: Dâru'l-Fikr, 1996), 5/139; Zehebî, Târîhu'lİslâm ve vefeyâtül'-meşâhîr vel'-alâm, thk. Ömer Abdüsselam Tedmürî (Beyrut: Dârü'l-Kitâbi'l-Arabî, 1990), $4 / 94$.

8 İbn Abdülber, el-ìstîâ, 4/1446.

9 İbn Sa'd, et-Tabakât, II/351; İbn Abdürabbih, el-îkdül-ferîd, thk, Abdülmecid et-Tarhîn̂i (Beyrut, 1983), 5/296.

10 İbn Sa‘d, et-Tabakât, II/351; Belâzürî, el-Ensâb, 8/5717; İbn Abdülber, el-istîâb, 4/1446; İbnü'l-Esîr, İzzeddin, elKâmil fitt-târîh (Beyrut: Dâru Sâdır - Dâru Beyrût, 1965), 3/408; a.mlf. Üsdül'-gâbe fi márifeti's-sahâbe (Beyrut, ts.), 5/248; Zehebî, Siyeru alâm, 3/ 22; ibn Kesîr, Ebü'l-Fidâ, el-Bidâye ve'n-nihâye (Beyrut: Mektebetü'l-Maârif - Riyad: Mektebetü’n-Nasr, ts.), 8/49; ibn Hacer el-Askalânî, el-isâbe fitemyîzi's-sahâbe (Beyrut: Dârü'l-ihyyâi'tTürâsi'l-Arabî,ts.), 3/452; A.Cevdet Paşa, Kisas-lEnbiyâve Tevârihh-iHulefâ (istanbul:Kanaat Kütübhanesi, 1331 H.), 8/160; Mustafa Asım Köksal, İslam Tarihi:Hazreti Muhammed (a.s.) ve İslamiyet: Medine Devri (istanbul: Şamil Yayınevi, 1981), 4/341.

11 Köksal, İslâm Tarihi, 4/341. 
Dühât-1 Arab şeklinde darb-1 mesel olmuşlardır. Ancak, ifade etmek gerekir ki, bu isimleri bir araya getiren tek ortak vasıf "dehâ" değildir; onlar, aynı zamanda gerek yaşadıkları ve gerekse sonraki dönemlerde "hitabet" hususundaki maharetlerine atfen Arapların hatiplerinden sayılmışlardır.

Dühât-1 Arab hakkında, bu tür genel rivayetlerin yanında, onlardan sadece birinin dehâsından hususen bahseden rivayetler de vardır ki, bunlara değinmek, söz konusu kişilere dair genel bir kanaatin oluşması ve ileride işlenecek konular bağlamında bir hazırlık niteliğinde olacaktır. Buna göre, söz konusu rivayetlerin bir kısmı Amr'ın dehâsına yönelerek, onun ihtiyatlılık ve akıllılık yönünden Arap dâhilerinden olduğunu belirtirken; ${ }^{12}$ bir diğeri onun dünyevî işlerde, hilede, uyanıklık ve cin fikirlilikte dâhi olduğunu, ${ }^{13}$ bir diğeri de onun tüm bu özellikleri birleştirecek şekilde darb-1 mesel olduğunu söyler. ${ }^{14}$

Arap dâhilerinden bir diğeri olan Mugîre b. Şu'be hakkında da benzer özel rivayetler vardır:

"Bir şehrin sekiz kapısı olsa ve her birini açmak için ayrı bir hile gerekse, Mugîre bir yolunu bularak kapıların hepsini açar". ${ }^{15}$

"Mugîre b. Şu'be'nin içinden çıkamayacağı, üstesinden gelemeyeceği, ona galip gelecek hiçbir iş yoktur". ${ }^{16}$

Ayrıca Mugîre b. Şu'be'nin dehâsına izafeten Araplar arasında "Mugîre görüşlü" şeklinde bir darb-ı mesel oluştuğu; zeki ve ileri görüşlü insanlar için bu kalıplaşmış ifadenin kullanıldığı belirtilir. ${ }^{17}$

Arap dâhilerinin bir diğeri olan Ziyâd b. Ebîh hakkındaki hususî rivayetler de hayli dikkat çekicidir. Bunlardan bazısı, onun, ne sohbeti (sahabîlik), ne (hadis) rivayeti, ${ }^{18}$ ne soylu bir geçmişi ne de aşireti olmasına rağmen ${ }^{19}$ sırf dehâsıyla devletin en üst kademelerinde yer edinmeyi başarmış nadir bir isim olduğunu belirtirken, bazısı da bu dehâsı ve akıl gücünün fazlalığı nedeniyle onun görevden dahi azledildiğini söyler. ${ }^{20}$

12 Yakûbî, Târîhül'-Yakûbî (Beyrut: Dâru Sâdır, 1960), 2/221.

13 İbn Abdülber, el-İstîab, 3/1188.

14 Zehebî, Siyeru alâm, 3/55.

15 Süyûtî, Târîhu'l-Hulefâ, 231; İbn Kesîr, el-Bidâye, 8/49; İbn Hacer , el-ísâbe, $3 / 452$.

16 İbn Hacer, el-ìsâbe, 3/453.

17 Zehebî, Siyeru alâm, 3/21; Cevad Ali, el-Mufassal fi târîhi'-Arab kable'l-İslâm (Beyrut: Dâru'l-İlm li'l-Melâyîn, 1993), 8/129.

18 İbn Abdülber, el-İstîab, 3/1188.; İbnü'l-Esîr, Üsdü'l-gâbe. 5/248; Nüveyrî, Ahmed b. Abdülvehhâb, Nihâyetü'l-ereb fîünûni'l-edeb, thk. Müfîd Kumeyha (Beyrut, 2004), 20/214.

19 Kütübî, Fevâtü'l-vefeyât, thk İhsan Abbâs (Beyrut: Dâru Sadır, 1973), 2/33; Safedî, el-Vâfi bi'l-Vefeyât, thk. Ahmed el-Arnaut - Mustafa Türkî (Beyrut: Dâru İhyâi't-Türâsi'l-Arabî, 2000) 15/8; Hayreddin Zirikli, elAlâm:Kamusu terâcim (Beyrut: y.y., ts.), 3/9.

20 Rivayetlere göre Hz. Ömer Ziyâd'a, onu, herhangi bir acziyet veya hıyanetinten dolayı değil; sadece aklının fazlalığını halka yüklemek istemediği için kâtiplikten azlettiğini söylemişti. İbn Kuteybe, Uyûnü'l-Ahbâr (Kahire: Dârü'l-Kütübi'l-Mısriyye, 1996), 1/329; İbn Abdürabbih, el-íkdü'lferîd, 5/272-273; İbn Hallikân, Vefeyâtü'l-A'yân ve enbâü ebnâi'z-zamân, thk. İhsan Abbas (Beyrut: Dâru Sâdır, ts.), 6/356. 
Dehâsıyla darb-1 mesel olduğu belirtilen Ziyâd ${ }^{21}$ hakkında gelen bir diğer rivayet ise adeta onun şahsiyetini özetler mahiyettedir: "Ziyâd, dehâ sahibi, akıllı, zeki, ileri görüşlü, basiretli, kararlı, ihtiyatlı ve sağlam (duruşlu) biri idi”. ${ }^{22}$

Dühât-1 Arabın dördüncüsü ve içlerindeki tek halife olan Muâviye b. Ebî Süfyân ise, Emevî Devletinin kurucusu olup, diğer üç dâhiyi kadrosunda toplamak suretiyle hepsinin kesişme noktası olmuş, kendi dehâsını onlarınkiyle birleștirerek gücüne güç katmayı bilmiştir. Onun, meseleleri enine boyuna düşünerek sükûnetle hareket eden, ${ }^{23}$ acelecilik tuzağına düşmeyip, öncesini ve sonrasını hesap ederek temkinli davranan bir dâhi olduğu ifade edilmiştir. ${ }^{24}$

Son olarak, annesi Hind binti Utbe'nin ağzından Muâviye'nin dehâsını anlatan şu rivayeti de aktarmak uygun olacaktır: “...Her taraftan Araplar toplansa ve Muâviye de onların içine -tek başına- bırakılsa, o, istediği şeyi elde etmiş bir şekilde aralarından çıkmayı becerir." 25

Dehâları hakkında zikrettiğimiz bu genel ve özel rivayetlerin ardından Dühât-1 Arab dörtlüsünün her birinin -hayatına kısaca değindikten sonra- hitabet özelliklerine, bu alanda öne çıkan yönlerine değinmek ve onları örnekleriyle beraber ana hatlarıyla değerlendirme sürecine geçmek uygun olacaktır. Bu anlamda, Dühât-1 Arab'ın doğup büyüdüŭü çevreye, hayat hikâyelerine kısaca değinmenin, onları hem dâhi hem de hatip olarak anılmaya götüren sürecin anlaşılması açısından önemli olduğu kanaatindeyiz.

\section{Amr b. el-Âs ve Hitabet Yönü}

Kureyş kabilesinin Sehmoğulları kolundan olan Amr b. el-Âs, Mekke'de doğmuş olup, annesi bir cariye olmakla birlikte, babası Mekke'nin önde gelen şahsiyetlerinden ve zengin tüccarlarından Âs b. Vâil idi. ${ }^{26}$ Büyük ihtimalle Mekke'nin fethinden önce Müslüman olan Amr'ın ${ }^{27}$ İslamiyet'ten önce iyi bir siyaset ve ticaret tecrübesi edindiği; nitekim Müslüman olduktan sonra Hz. Peygamber tarafindan komutanlık, elçilik, âmillik, ${ }^{28}$ kâtiplik gibi işlerde istimal edildiği kaydedilir. Hz. Ebû Bekir döneminde fetihlere ve Ecnadin, ${ }^{29}$ Yermük gibi kritik savaşlara iştirak eden

21 İbnü'l-İmâd, Şezerâtü'z-Zeheb fi Ahbâri Men Zeheb, thk. Abdülkadir Arnaut - Mahmûd Arnaut (Beyrut, Dâru İbn Kesîr, 1987), 1/252.

22 Zehebî, Siyeru alâm, 3/495.

23 İbn Sa'd, et-Tabakât, 2/351; İbn Asâkir, Târîhu medîneti Dımaşk, 19/182.

24 Belâzürî, el-Ensâb, 5/139; Zehebî, Târîhu'l-ìslâm, 4/94.

25 Câhiz, el-Beyân ve't-Tebyîn, thk. Abdüsselam Muhammed Harun (Kahire: Dâru'l-Cîl, 1968), 1/56; İbn Abdürabbih, el-Ikdü'l-Ferîd, 2/325.

26 İbn Sa'd, et-Tabakât, 2/351; İbn Abdülber, el-İstîâb, 3/1184-1185.

27 İbn Hişam, es-Sîretü'n-Nebeviyye, thk. Mustafa es-Sakka v.dğr. (Kahire: Mustafa el-Bâbî el-Halebî, 1955); 3/222; İbn Abdülber, el-ìstîâb, 3/1185.

28 İbn Sa'd, et-Tabakât, I/263; Belâzürî, Fütûhu'l-Büldân, thk. Abdullah Enis et-Tabbâ - Ömer Enis et-Tabbâ (Beyrut: Müessesetü'l-Maârif, 1987), 105.

${ }_{29}$ Taberî, Muhammed b. Cerir, Târîhül'-ümem ve'l-mülûk, thk. Muhammed Ebü'l-Fazl İbrahim (Beyrut: Dâru Süveydân, 1970), 3/418; İbnü'l-Esîr, el-Kâmil, 2/287. 
Amr, ${ }^{30} \mathrm{~Hz}$. Ömer zamanında ise büyük bir önem ve özenle istediği Mısır'ın fethini gerçekleştirerek "Mısır fatihi" olmuş ve Halife tarafından buranın valiliğine atanmıştır. ${ }^{31}$

Hz. Osman döneminde görevinden azledilen Amr, bir müddet beklemeye çekilmiş; Hz. Ali halife olduğunda ise bundan memnun olmadığını belirterek ona beyat etmemiştir. $^{32}$ Bir süre sonra da yüzünü Muâviye'ye dönmüş ve Hz. Ali'ye karşı aktif muhalefetin bir parçası olmuştur..$^{33}$ Amr'ın bu süreçte Muâviye'ye sağladığı katkının büyüklüğünü anlatmak için, malum olduğu üzere, onun, Muâviye'nin Hz. Ali'ye karşı kaybetmek üzere olduğu Sıffîn Savaşını kurnazca bir teklifle son anda durdurarak akışı tersine çevirmesi bile tek başına kâfidir. Bundan sonra Hz. Ali'nin Mısır valisini bertaraf etmek suretiyle Mısır'ı Muâviye'ye kazandıran Amr, ölene dek, çok sevdiği bu şehrin valiliğ̈ini yürütmüştür. ${ }^{34}$

İslam tarihinde komutan, elçi, vali vb. gibi birçok vasflyla öne çıkan dâhi şahsiyetlerden olan Amr b. el-'As, yanı sıra, iyi bir hatip ve şair idi. Öyle ki onun bazı beyitleri Arap edebiyatında "şâhid" mertebesinde yani hüccet ve delil olarak gösterilecek kadar sağlam ve değerliydi. ${ }^{35}$

Amr b. el-Âs, hitabet yönünden de Arap toplumu içerisinde önemli bir yere sahipti. $O$, güzel ve etkileyici konuşma sanatını ifade eden hitabetten ayrı düşünülemeyecek olan belagat (ifadedeki güzellik, kısa, veciz konuşma) ve fesahat (açık, net, anlaşılır olma) bakımından da referans kabul edilen isimlerdendi. Öyle ki, onun hitabetini ne kadar beğendiğini gizlemeyen Hz. Ömer, kendini ifade etmeyi beceremeyen insanları dinlediğinde, “Amr'ı da bu konuşanı da Allah yarattı" diyerek onun hitabet kabiliyetini örnek gösterirdi. ${ }^{36}$

Kaynaklarda hitabet noktasında örnek gösterilen isimlerden olan Amr'in bizzat kendisi de güzel bir hitabetin nasıl olacağına dair fikir belirtmiş; bir rivayette belagatten bahsederken onu "laf kalabalığından uzaklaşarak az ve öz konuşmak" şeklinde tanımlamıştır. ${ }^{37}$

Amr b. el-Âs'ın hitabet yeteneğini gözler önüne seren en somut örneklerden biri olarak şu hutbesini göstermek mümkündür:

Ey insanlar, şu dört huya dikkat ediniz! Çünkü bunlar rahatlıktan sonra sıkıntıya, genişlikten sonra darlığa, izzetten sonra zillete sebep olur. Buna göre, ailenin (baş edemeyeceğiniz) çokluğundan, kötü bir hale düşmekten, malı zayi

30 Belâzürî, Fütûh, 179.

31 Taberî, Târîh, 4/241 vd; İbnü'l-Esîr, el-Kâmil, 3/40 vd.

32 Taberî, Târîh, 4/560; İbnü'l-Esîr, el-Kâmil, 3/141.

33 Yakûbî, Târîh, 2/185; Taberî, Târîh, 4/560.

34 İbn Sa'd, et-Tabakât, 4/258; Zehebî, Siveru alâm, 3/73.

35 Lügat, sarf, nahiv ve belâgat ilimlerinde, bir kelimenin va da ifadenin lafız, anlam ve kullanım doğruluğunu kanıtlamak amacıyla müracaat edilen, doğruluğu kesin olan, örnek nazım ve nesir anlamında kullanılır; bk. Ahmet Önkal, “Amr b. Âs”, Türkiye Diyanet Vakfi İslâm Ansiklopedisi (İstanbul: Türkiye Diyanet Vakfi Yayınları, 1991), 3/80.

36 İbn Kuteybe, Uyûnül-Ahbâr, 2/171; Ya'kûbî, Târîh, 2/122; Zehebî, Siyeru alâm, 3/57.

37 İbn Asâkir, Târîhu medîneti Dımaşk, 49/185. 
etmekten ve dedikodudan sakınınız. Bilesiniz ki, kişinin bedenini dinlendirmesi, işlerini idare etmesi ve isteklerini yerine getirmesi için boş vakte ihtiyacı vardır. O halde kim bunu elde ederse, doğru kullansın ve en aza kanaat etsin. Kişi boş vaktinde ilimden de nasibini zayi etmesin. Yoksa hayrı olmayan ve Allah'ın helal-haramlarından gafil biri olur.

Ey insanlar, ikizler burcu aşağıya doğru sarktı, Şira yıldızı parladı. Yağmur kesildi, veba ortadan kalktı, çiğ azaldı, otlar çok güzel oldu, hamileler doğurdu ve oğlak-kuzular yürüdü. Çobanın sürüsünü iyi gütmesi gerekir. Haydi, Allah'ın bereketiyle gelin köylerinize. O hayvanların bereketinden, sütünden istifade edin. Atlarınızı otlağa salın, besleyin, koruyun, saygı gösterin. Çünkü onlar, sizin düşmana karşı kalkanlarınızdır. Onların yardımıyla ganimet elde ediyorsunuz. Komşunuz olan Kıptîlere de iyi muamele edin. Güzel kokulu ve işveli kadınlardan sakının zira bunlar dininizi bozar ve gayretlerinizi zayıflatır. ${ }^{38}$

Amr'ın hitabet kabiliyetini en iyi yansıttı̆̆ı, eleştiri, nasihat, tavsiye, uyarı gibi birçok unsuru içeren konuşmalarının önemli bir bölümü de siyasî nitelikli olup, Hz. Osman'la gerçekleştirdikleri istişare toplantılarında yaptığı konuşmalar bunun bariz örnekleridir. Bu toplantıların ilkinde Amr, Hz. Osman'a “Görüyorum ki sen, insanların sırtına hoşlanmadıkları şeyleri yükledin. Ya adaletli olmaya azmet ya da görevi bırakmaya (azmet); (bırakamayacaksan) görevini hakkıyla yap". ${ }^{39}$ "Sen insanları Ümeyyeoğulları gibi/onlarla birlikte yönettin; Sen söyledin, onlar da söylediler; sen doğru yoldan saptın, onlar da saptılar. O halde ya adil ol ya da istifa et; etmezsen de işinde kararlı ol, sözünü geçir" demişti. ${ }^{40}$ Bir yıl sonraki istişare toplantısında ise Halifeye çok daha açlk ve net ifadelerle, eleştiri eşliğinde tavsiyelerde bulundu: "Kanaatim odur ki sen onlara (valilere) çok yumuşak davrandın, gevşek bir duruş sergiledin ve Ömer'in yapmadığı kadar onları (yetkilerini) arttırdın. Bence sen, senden önceki (halife)lerin yolundan git ve şiddet gereken yerde şiddet, yumuşaklık gereken yerde yumuşaklık yolunu tut". ${ }^{41}$

Amr'ın etkili hitabetine örnek olarak sunmayı uygun bulduğumuz bir diğer rivayet ise, onun ölüm döşeğinde iken, oğlu Abdullah'a söylediği şu sözleri içermektedir:

oğlum, ben üç dönem geçirdim ve kendimi bu üç dönemde tanıdım. Ben ilk önce kâfirlerden ve Resûlullah'a en çok düşmanlık edenlerden biriydim; şayet o zaman ölseydim kendimi Cehennem'de bulurdum. Sonra Allah Resûlü'ne (a.s.) beyat ettim; bu kez de (önceki yaptıklarımdan dolayı) ondan en çok utanan kişi oldum; öyle ki, vefatına dek ona gözlerimi kaldırıp bakamadım. Eğer o

38 İbn Tağrîberdî, en-Nücûmü'z-Zâhire fi Mülûki Misr ve'l-Kâhire, tkd. ve tlk. Muhammed Hüseyin Şemseddin (Beyrut: Dâru'l-Kütübi'l-İlmiyye, ts.), I/91; İbn Asâkir, Târîhu medîneti Dımaşk, 49/162-163.

39 Rivayetin devamına göre Hz. Osman, Amr'a gerçekten böyle mi düşündüğünü sormuş, Amr da herkes gittikten sonra ona, bunların aslında gerçek fikirleri olmadığını ancak "hayrı celb şerri def için" insanların böyle bilmesinin daha iyi olacağını söylemişti. Bu konudaki değerlendirmeler için bkz. Apak, Amr b. el-Âs, 128-129.

40 Ya'kûbî, Târîh, 2/175; Taberî, Târîh, 5/334-335; İbnü’l-Cevzî, Ebü'l-Ferec, el-Muntazam fî târîhi'l-mülûk ve'lümem, thk. Muhammed Abdülkadir Atâ - Mustafa Abdülkadir Atâ (Beyrut: Dâru'l-Kütübi'l-ïlmiyye, 1992), 4/44; İbnü'l-Esîr, el-Kâmil, 3/42.

41 Taberî, Târîh, 5/342-343; İbnü'l-Esîr, el-Kâmil, 3/47. 
zaman ölseydim, insanlar “Ne mutlu Amr'a ki Müslüman oldu, hayırlı bir hayat yaşadı ve öyle de öldü" diyeceklerdi ve benim varacağım yer Cennet olacaktı. Ben bundan sonra ise birtakım işlere karışıım ki bunlar benim lehime midir aleyhime midir bilmiyorum... ${ }^{42}$ Ben şirk üzere değilim ki, öldüğümde Cehennem'e atılayım; İslam üzere de değilim ki, öldüğümde Cennet'e koyulayım. ${ }^{43}$

Görüldüğü üzere, Amr'ın hitabeti ve bu hitabete konu olan hususlar hayatın her alanına dokunabilen, zaman ve mekân sınırlarını aşabilen nitelikte ifadelerle, tasvir, tarif ve teşbihlerle mücehhezdir. Bu meyanda onun veciz sözlerinden aktarmayı uygun bulduğumuz birkaç tanesi şöyledir:

"İnsanların en sabırlısı, hevasına bağlı düşünceleri zihninden atan; en cömerti, dini için dünyasını harcayan; en cesaretlisi ise, cehaletini hilmi ile bertaraf edendir" ${ }^{4}{ }^{4}$

"Kendisine ulaşana ulaşan değil, kendisinden ayrılana ulaşan kişi, hedefe ulaşmiş olur". 45

"Akıllı kişi, hayırlıyı şerliden ayırt edebilen değil, iki şerli arasında hayırlı olanı bilebilendir". ${ }^{46}$

"Ölüm, anlatmaktan öte bir şeydir ama (yine de anlatayım); sanki şu anda sırtımda Radva dağı, boğazımda ise hurma dikeni var ve sanki nefesim iğne deliğinden geçmektedir." 47

"Dünyamdan az şeyi düzelttim, dinimden çok şeyi bozdum. Keşke düzelttiğim bozduğum, bozduğum da düzelttiğim olsaydı, işte o zaman kurtulurdum" ${ }^{48}$

Amr b. el-Âs, etkili hitabetinin yanı sıra kitabet/yazım noktasında da mahir idi. Bu aşamada onun, hayranı olduğu Mısır'ı Hz. Ömer'e özenli ve süslü bir üslupla anlattığı, tasvir, teşbih, teşhis/kişileştirme, mübalâğa, mecaz gibi edebî sanatlarla dolu mektubu, özellikle zikre şayandır:

Mısır, beyaz tozlu bir yerleşim yeridir. Yeşil ağaçl, uzunluğu bir ay, genişliği on günlük bir mesafedir. Ülkeyi toz renkli bir dağ ve kırmızımsı bir kum kucaklamaktadır. Ortasında ise, akşam akışı mübarek, sabah akışı bereketli (her daim bereketli) Nil vardır. Nil'in akışı Güneş ve Ay gibi bazen azalır, bazen de çoğalır. Suyun çoğaldığı vakitler vardır -ki-sineklerin de çoğaldığı bu vakitlerde diğer dereler ona katılır, böylelikle suları iyice çoğalınca ve dalgaları büyüyünce iki tarafa da taşar. Yerleşim yerlerinin birinden diğerine ancak küçük gemi ve hafif kayıklarla geçilir. Bu kayıklar, boz renkleriyle, ikindi vaktinin boz güvercinleri gibi süzülürler. Nil'in yükselişi son noktaya ulaştığında ise topukları üzerinde geri dönerek -akışında- ilk haline döner ve bereketi artar. İște o zaman, hakir dinin ve korunan zimmetin mensupları çıkarlar, toprağı sürerler, tohumlarını atarlar, böylece kendileri kadar çalışmayan başka kimseler için Rab'den

${ }^{42}$ İbn Sa'd, et-Tabakât, 4/258; İbn Abdülber, el-isttîab, 3/1160; íbn Asâkir, Târîhu medîneti Dımaşk, 46/193-194.

43 İbn Abdürabbih, el-Ikdül-ferîd, 3/189.

44 İbn Asâkir, Târîhu medîneti Dımașk, 46/185.

45 İbn Asâkir, Târîhu medîneti Dımaşk, 46/186.

46 İbn Asâkir, Târîhu medîneti Dimașk, 46/186; Zehebî, Siyeru alâm, 3/74.

47 İbn Sa'd, et-Tabakât, 4/260; İbn Asâkir, Târîhu medîneti Dımaşk, 46/186.

48 İbn Abdülber, el-Istîâb, 3/1189. 
bereket umarlar. Ekinler tomurcuklanıp çiçek açtığında çiğ onları sular, alttan da toprak besler. Ey Mü'minlerin emiri, Mısır, beyaz bir inci iken siyah bir anbere dönüştüğü zaman, ardından yemyeşil bir zümrüde, sonra benekli bir ipeğe dönüşür. Allah dilediğini mübarek kılar. Bu ülkeyi ıslah edip geliştiren ve oturanlarının burada oturmasına sebep olan şey, iyisinin hakkında kötüsünün sözünün kabul edilmemesidir. Toprağın haracının vaktinde alınması, gelirin üçte birinin köprü ve kanal yapımına harcanmasıdır. Amillerin durumu böyle olunca da malın bereketi katlanır, başta da sonda da muvaffak kılan Allah'tır. ${ }^{49}$

Mısır'ın velud topraklarını, canlılığını, gelişmişliğini göz ardı edilemeyecek değerdeki bereketini ve güzelliğini -sebepleriyle- gözler önüne seren ifadelerle donanmış bu mektup karşısında Hz. Ömer ise, adeta Mısır'ı gezip görmüş gibi olduğunu söyleyerek bu hoş anlatımın üzerinde bıraktığı etkiyi dile getirmişti. ${ }^{50}$

Amr'ın, Müslümanlar için bir ilk olacak olan (Kıbrıs) deniz seferine çıkma isteğine binaen yine Hz. Ömer'e yazdığı bilgilendirme amaçlı olan şu mektup, sade, akıcı ve karmaşık olmayan üslubuyla, anlaşılır betimlemeleriyle, Amr'ın hitabetini yansıtan bir diğer örnektir:

Ben büyük bir topluluğun küçük bir şeye bindiğini gördüm. Altlarında su, üstlerinde sema vardır. Deniz sakin olursa, kalplere heyecan verir, dalgalı olursa akılları giderir; ondaki kesinlik az, şüphe ise çoktur. Bu insanların hali, suyun içindeki dalın üstünde duran kurtçuk gibidir; kıpırdarsa batar/boğulur, kurtulursa da korku içinde kalır. ${ }^{51}$

Hâsılı, söz konusu ifadelerde Amr'ın, karşılaştığı yeni durum veya olaylar karş1sında hissettiği heyecanı ya da duyguları, kendine has tasvir ve tahlillerin şekillendirdiği üslubuyla ânı yaşatırcasına anlattığını görmek mümkündür.

\section{Mugîre b. Şu'be ve Hitabet Yönü}

Mugîre b. Şu'be, Mekke'nin kardeş şehri konumundaki Taif'te doğmuş olup, Sakîf kabilesine mensuptur. ${ }^{52}$ Annesinin cariye, babasının azatlı bir köle oluşunun da etkisiyle olsa gerek, çocukluk dönemine dair hakkında çok az malumat bulunan Mugîre'nin, gençlik yıllarında genellikle ticaretle uğraştı̆̆ı belirtilir. ${ }^{53} \mathrm{O}$, Hendek Savaş ${ }^{54}$ veya Hudeybiye Musâlahası öncesi ${ }^{55}$ Müslüman olduktan sonra

49 İbn Tağrîberdî, en-Nücûm, 1/42-43. Amr'ın bu mektubu, Fransızların meşhur gazetesi Le Figaro'da Octave Ozen tarafından yayınlanmış; mektubun, dünyanın en güzel belagat örneklerinden biri olduğu belirtildikten sonra, tasvir gibi bir şeyin en güzel şekilde nasıl anlatılabileceği noktasında edebî hasletlerin geliştirilmesi bağlamında bütün okullarda okutulması gereken bir referans olarak gösterilmiştir; bk. Hasan İbrahim Hasan, Târîhu Amr b. el-Âs (Misır: Mektebetu Medbûlî, 1996), 194, naklen Apak, Amr b. el-Âs, s. 220, dn. 95.

50 İbn Tağrîberdî, en-Nücûm, 1/42-43.

51 Taberî, Târîh, 4/258-259.

52 İbn Kuteybe, el-Maârif, tashih Muhammed İsmail Savi, 2. bs. (Beyrut: Dâru İhyâi't-Türâsi'l-Arabî, 1970), 128; İbn Abdülber, el-ìstîab, 4/1446; Zehebî, Siyeru alâm, 3/32; İbn Kesîr, el-Bidâye, 8/48.

53 Belâzürî, el-Ensâb, 13/343; Zehebî, Siyeru alâm, 3/24-25.

54 İbn Abdülber, el-ìstîab, 4/1445; İbn Kesîr, el-Bidâye, 8/4, 195.

55 İbn Kuteybe, el-Maârif, 128; Belâzürî, Ensâb, 13/343; Zehebî, Siyeru alâm, 3/25; İbn Hacer , el-ìsâbe, $3 / 452$. 
adeta Hz. Peygamber'in yanından ayrılmamış; hâciplik, ${ }^{56} \mathrm{kâtiplik,}^{57}$ elçilik, ${ }^{58}$ vb. gibi birçok görevi başarıyla ifa etmiştir. Hz. Ebû Bekir döneminde irtidat edenlerle mücadeleye girişmiş, ${ }^{59}$ ayrıca Yermük Savaşına katılmıştır. ${ }^{60}$ Ardından Hz. Ömer döneminde özellikle, Sasanîlerle yapılan savaşlarda -askerî başarılarından ziyade- diplomasi görevini yürütürken yaptığı konuşmalarla dikkat çekmiştir. ${ }^{61} \mathrm{~Hz}$. Osman döneminde ise kısa bir süre valilik yaptıktan sonra görevden alınan Mugîre, aktif siyaset hayatına ara vermiş; Muâviye b. Ebî Süfyân iktidar oluncaya dek resmî bir görev üstlenmemiştir. Muâviye ise onun gibi donanımlı bir ismi derhal idarî kadrosuna katarak Kûfe valiliğiyle görevlendirmiştir. Bu süreçte şehirde iç asayişi büyük oranda temin etmedeki başarısı bir yana, onun Muâviye'ye belki de en büyük iyiliği, tıpkı kendileri gibi dehâ olan, Hz. Ali döneminin cevval valisi Ziyâd b. Ebîh'i Muâviye'ye kazandırmasıdır. ${ }^{62}$ Valiliğinin ilerleyen yıllarında, Muâviye'ye oğlu Yezid'i veliaht ilan etmesini tavsiye eden ve bu doğrultuda çalışmalar başlatan Mugîre ${ }^{63}$, bir süre sonra 50/670 senesinde veba salgını nedeniyle vefat etmiştir. ${ }^{64}$

Hitabetiyle ünlü devlet adamlarından olan Mugîre b. Şu'be, daha önce de değindiğimiz gibi, İran topraklarının fethi sürecinde, ordusunu savaşa motive eden şevklendirici konuşmalar yapmasının ${ }^{65}$ yanı sıra, bilhassa karşı tarafla gerçekleştirilen müzakereler sırasında dikkatleri üzerine çekmişti. Belirtildiğine göre o, İranlı komutanın huzuruna çıktığında, öyle beliğ, ustaca seçilmiş ifadelerden oluşan bir hitabet örneği sergilemişti ki, komutan orada bulunan kendi adamlarına "Bunlar nerede, siz neredesiniz..."demekten kendini alamamıșt1. ${ }^{66}$ Rivayete göre, gösteriş ve ihtişam dolu bir ortamdan geçerek komutanın yanına getirilen Mugîre'nin konuşması şöyleydi:

"Size dair bize rüya gibi şeyler anlatıldı; oysa gördüğüm o ki, sizden daha sefih bir topluluk yok. Sizler birbirinizi köle edinmişsiniz, aranızda adalet denen bir şey de yok. Keşke, sizin hakkınızda, bu sahte ihtişamınızı değil de birbirinizi

56 İbn Hişâm, es-Sîre, 3/327; Ya'kûbî, Târîh, 2/55; Taberî, Târîh, 2/627; íbnü'l-Esîr, el-Kâmil, 2/201-202; Zehebî, Siyeru alâm, 3/25; ibn Kesîr, el-Bidâye, 8/48.

${ }^{57}$ İbn Sa 'd, et-Tabakât, 1/266-268; İbn Abdürabbih, el-Ikdü'l-ferîd, 4/161; Cevad Ali, el-Mufassal, 8/122, 130; Muhammed Hamidullah, İslâm Peygamberi, çev. Salih Tuğ (isstanbul: İrfan Yayınları, 1990), 1/439.

58 Ebû Hanîfe ed-Dîneverî, el-Ahbâru't-Tivâl, thk. Ömer Faruk et-Tabbâ, ts.,114-115; Belâzürî, Fütûh, 358; Taberî, Târîh, 3/517-518.

59 İbn Kuteybe, Maârif, 128; íbn Kesîr, el-Bidâye, 8/48; ỉbn Hacer, el-İsâbe, 3/452.

60 İbn Kuteybe, Maârif, 128; İbn Abdülber, el-isttîab, 4/1445; Zehebî, Siyeru alâm, 3/21; İbn Kesîr, el-Bidâye, 8/48; İbn Hacer , el-İsâbe, 3/453; Cevad Ali, el-Mufassal, 8/129.

61 Dîneverî, el-Ahbâru't-tivâl, 114-115; Belâzurî, Fütûhu'l-Büldân, 358; Ya'kûbî, Târîh, 2/144; Taberî, Târîh, 3/517-518, 4/118; Mes'ûdî, Ali b. Hüseyin, Mürûcu'z-Zeheb ve meâdinü'l-cevher, thk. Muhammed Muhyiddin Abdülhamid (Kahire: el-Mektebetü't-Ticareti'l-Kübra, 4. Bs., 1964), 2/331-332.

62 Taberî, Târîh, 5/176-178; íbn Kesîr, el-Bidâye, 8/24.

63 Ya'kûbî, Târîh, 2/219-220; İbn Kuteybe, el-İmâme ve's-Siyâse, thk. Taha Muhammed ez-Zeynî (Beyrut: Müessesetü'r-Risâle, 1985), 142; ỉbnü'l-Esîr, el-Kâmil, 3/504; A. Cevdet Paşa, Kısas-ı Enbiyâa, 8/18.

64 Taberî, Târîh, 5/232; íbn Abdülber, el-Isttîâb, 4/1446; İbnü'l-Esîr, el-Kâmil, 3/461; Zehebî, Siyeru a lâm, 3/32; İbn Kesîr, el-Bidâye, 8/48.

65 Ya'kûbî, Târîh, 2/114; Taberî, Târîh, 3/533; İbnü'l-Esîr, el-Kâmil, 2/468.

66 Taberî, Târîh, 3/517-518; i̇bnü'l-Esîr, el-Kâmil, 2/464-465. 
rab edinmiş olduğunuz gerçeğini duymuş olsaydık. Bilin ki, hiçbir millet bu şekilde daim olamaz".

Mugîre'nin bu sözlerinin ardından İranlı komutanın kendilerini tazim, Müslümanları ise tahkir ve tehdit içeren cümleler sarf etmesi üzerine, Mugîre sözlerini şöyle sürdürdü:

Hamd olsun, şüphesiz her şeyi yaratan da rızıklandıran da Allah'tır. Övündügünüz her şeyi size veren de Allah'tır. Bizim geçim darlığ 1 içerisinde olduğumuz doğrudur. Allah, dünyada bizi böyle imtihan etmektedir; dünya ise gelip geçicidir. Siz, Allah'ın size verdiklerine mukabil ne kadar şükretseniz azdır; ama zaten sizi bu duruma (nimetleri kaybetmeye) getiren şey şükürsüzlügünüzdür. (Öte yandan) Biz, daha önce başımıza gelen sıkıntılar döneminde kâfir insanlardık; şimdi ise Allah, Resûlünü göndererek bize rahmet eylemiş ve bizi güçlü kılmıştır. Bundan sonra siz, artık ister İslam ile şereflenir ister cizye ödersiniz; aksi halde savaş kaçınılmazdır... Bizden öldürülenler cennet'e, sizden ölenler cehenneme gider; geride kalanlarımız ise yine size galip gelir. ${ }^{67}$

Mugîre'nin hitabet gücüyle ilgili bir diğer rivayet de yine Hz. Ömer döneminde onunla yaşadığı bir diyaloga dayanır. Buna göre, halife olduğunda, Kûfe’ye kimi vali tayin edeceğine karar vermekte zorlanan Hz. Ömer'e şu veciz sözleriyle yardımcı olmuştu: "Müttaki kişinin Müslümanlığı kendine, zayıflığı ve getireceği idare yükü senin sırtınadır. Lakin güçlü kimsenin Müslümanlığı kendisinin, güçlü yönetimi ise tüm Müslümanların malıdır". Siyasete vâkıf olduğunu gösteren, tesir gücü yüksek, akıl ve gözlem dolu, yol gösterici bu ifadelerin ardından Mugîre, bir kez daha Hz. Ömer'in takdir ve beğenisini kazanmıştı ${ }^{68}$

Yine, benzer bir rivayete göre, Muâviye'nin Abdullah b. Amr b. el-Âs'1 Kûfe'ye vali tayin ettiğini öğrenen Mugîre, Muâviye'ye: “Abdullah'1 Kûfe'ye, babası Amr'1 da Mısır'a vali yapmakla aslanın iki dişleri arasındaki bir emir mi olmak istiyorsun?" diyerek onu etkilemeyi başarmış; bu sözlerin ardından Muâviye fikir değiştirerek Abdullah'ın yerine Mugîre'yi vali yapmaya karar vermiști. ${ }^{69}$

O halde, Mugîre'nin hitabetine dair söylenmesi gereken belki de en temel özellik, sahip olduğu ikna kuvvetidir. Bu durumun en bariz örneklerinden biri ise, şüphesiz ki onun Ziyâd b. Ebîh'i Muâviye'ye kazandırma başarısıdır. Nitekim Muâviye iktidara geldiğinde, Ziyâd'la karşı saflarda olmaktan huzursuzluk duymakta; kabiliyetlerini çok iyi bildiği Ziyâd'ın yeni bir hareket başlatmak suretiyle iktidarını sarsabileceğinden endişe etmekteydi. Bu durum karşısında Mugîre ona: “Yâ Emîre'l-Mü’minîn! Bil ki Ziyad emin bir kişidir, tedbir ehlidir. O senin yanına gelirdi ama kendisinden, idare ettiği vilayetlerin mallarına dair hesap sorulacağı fikriyle ihtiyatlı davranmaktadır. Zira o, hesap vermekten acizdir; çünkü malları Hz. Ali’ye vermiştir; ancak delili yoktur. Oysa sen ondan delil isteyeceksin. Şayet bu hesap işinden vazgeçersen, onu

67 Dîneverî, el-Ahbâru't-Tıvâl, 114-115; Belâzürî, Fütûh, 358; Taberî, Târîh, 3/517-518.

68 Taberî, Târîh, 3/517-518; İbnü'l-Esîr, el-Kâmil, 2/464-466.

69 İbnü'l-Esîr, el-Kâmil, 3/413; İbn Kesîr, el-Bidâye, 8/22. 
hemen senin yanına getiririm" diyerek Muâviye'yi hesap işinden vazgeçirmiş; ardından da Ziyad'ın yanına giderek onu bir an evvel Muâviye'ye beyat etmeye ikna etmişti. ${ }^{70}$ Buna göre Mugîre, Ziyad'a giderek ona şunları söylemişti: "Hilafet konusunda ortaya çıkıp bu işe elini atacak Hz. Hasan'dan başka kimse yoktur ki, o da Muâviye’ye beyat etmiştir. Buna rağmen, senin burada olman halifeyi rahatsız etmektedir. Bu nedenle beni sana gönderdi. Sen de beyat hususunda acele et ki, Muâviye seninle uğraşmaktan vazgeçsin... Onunla bir araya gel; barışın ve iplerinizi birleştirin. Yüce Allah, sonunda hükmünü verecektir". ${ }^{71}$

Mugîre b. Şu'be'nin bir vali olarak irad ettiği hutbelerinde de etkili hitabetiyle karşılaşmak mümkündür. Nitekim o, Muâviye tarafından Kûfe'ye vali tayin edildiğinde, başta Haricîler olmak üzere muhalif gruplara, herhangi bir eyleme kalkışmadıkça kendilerine dokunulmayacağını vaad etmesine rağmen, beklediği karşılı̆̆ bulamamış, bunun üzerine onlara şöyle seslenmişti:

Ey insanlar, benim sizin iyiliğinizi istediğimi, üzerinizden eziyeti kaldırdığımı gördünüz. (Ancak) vallahi, aranızdaki bazı sefih kimseler yüzünden kötü bir şeyler olacağından endişe etmekteyim. Halim ve müttaki insanlara gelince, evet (böyle giderse) gerçekten, cahil ve sefih birinin günahını hilm ve takva sahibi kimselere yüklemekten başka bir çıkar yolumuzun kalmayacağından, Allah'a yemin olsun ki korkuyorum. O halde ey insanlar, belâ/musibet hepinizi kuşatmadan önce içinizdeki sefihleri tutun/bertaraf edin. Aranızdan bazılarının bu şehirde nifak ve fitnenin hâkim olmasını istediğinden haberdarım. Yine Allah'a yemin olsun ki, bu şehrin neresinde isyan ederlerse etsinler, mutlaka onları yok eder ve kendilerinden sonra gelecek olanlara ibret haline getiririm. (Öyleyse) herkes iyice düşünsün. Ben, bu hususta hiçbir hacet veya mazeret kabul etmeyeceğimi de söylemek üzere buradayım. ${ }^{72}$

Mugîre'nin hitabetteki ustalığına, bilhassa ikna edici üslubuna örnek olabilecek bir başka rivayet de, onun, Yezid'in veliaht ilan edilmesi gerektiği fikrini ortaya atmasıyla ilgilidir. Rivayete göre Mugîre, iktidar rahatsız edecek derecedeki müsamahalı yönetimi yüzünden Muâviye tarafından azledileceğini hissedince harekete geçmiş, önce Yezid sonra da Muâviye’yle görüşerek veliahtlık fikrini sebep ve sonuçlarıyla onlara anlatmıştı. O, Yezid'e: "Resûlullah'ın en yakın arkadaşları, Kureyş’in büyüklerinin hepsi öldü, geriye ise onların evlatları kaldı. Sen, bu evlatlar içinde en üstün, ileri görüşlü, sünneti, siyaset ve yönetim işlerini en iyi bilen kişisin. Hal böyleyken, mü'minlerin emîrini, kendisinden sonra senin için beyat almaktan alıkoyan nedir, bilmiyorum" diyerek, onu cesaretlendirmiş, ${ }^{73}$ ardından da Muâviye'ye şunları söylemişti: “Ey Mü’minlerin Emîri! Görüyorsun ki, Hz. Osman'ın öldürülmesinden sonra birçok ihtilaflar meydana geldi, Müslüman kanı döküldü. Yezid, senin halefin

70 Taberî, Târîh, 5/176-178; İbn Kesîr, el-Bidâye, 8/24.

71 Taberî, Târîh, 5/184; İbnü'l-Esîr, el-Kâmil, 3/422-423; İbn Kesîr, el-Bidâye, 8/24.

72 İbnü’l-Esîr, el-Kâmil, 3/426-427; Kenan Seyithanoğlu vd., Doğuştan Günümüze Büyük İslâm Tarihi: Hulefâ-i Râşidîn ve Emevîler (Konya: Kombassan Şirketler Topluluğu, 1994), 2/297-298.

73 İbnü’l-Esîr, el-Kâmil, 3/503; A. Cevdet Paşa, Kısas-ı Enbiyâ, 8/181; Hasan, İslâm Tarihi, 1/357; Seyithanoğlu vd., Doğuştan Günümüze, 2/307. 
olsun; onun adına insanlardan beyat al. Böylece, senin vefatından sonra o, Müslümanları korur, kan dökülmez ve herhangi bir fitne meydana gelmez... Kûfelileri ben ikna ederim; Basra'yı da Ziyad halleder. Zaten bu şehirler sana beyat ettikten sonra, diğerlerinin muhalefet edecek hâli yok" ${ }^{74}$

İlginçtir ki, rivayetin devamına göre, Mugîre oradan ayrıldıktan sonra şunları söylemişti: "Muâviye'nin kafasına, hiç olmayacak bir iş soktum. Bu iş, Muhammed ümmetinde olması asla uygun olmayacak bir şeydir. Ancak ben onlar için öyle bir gedik açtım ki, ebediyen kapanmayacaktır". ${ }^{75}$

Son olarak, yönetimdeki müsamahası nedeniyle kendisini eleștirenlere cevaben ağzından dökülen şu manidar cümleler de Mugîre'nin aklını gözler önüne seren hitabet kabiliyetine güzel bir örnektir:

"Ben, şu ilerlemiş yaşımda, ecelimin yaklaştığı ve takatimin azaldığı bir zamanda, şehrin ileri gelenlerini öldürmek, onların kanını akıtmak suretiyle iş hallederek, onları saâdete, kendimi ise şekâvete sürüklemek istemem. Şayet böyle yaparsam (onları öldürürsem), Muâviye'nin dünyasını imar ederken, kendi ahiretimi viran etmiş olurum. Oysa ben, bu halkın iyileri ile dost olur, kötülerini bağışlarım; akıllılarını över, akılsızlarına ise nasihat ederim; ta ki ölüm bizi ayırana dek... (Zaten ben öldüğüm zaman) benden sonraki valileri görecekler; işte o zaman beni çok anacaklar/hatırlayacaklar". ${ }^{76}$

Mugîre'nin yazı yazmadaki kabiliyetine dair örnekler ise kaynaklarda -diğer üç dâhi isimle mukayese edilemeyecek derecede- az olup metin halinden ziyade kısa ve öze yönelik birkaç cümleyle belirtilmiş olan mektuplarla ilgilidir. ${ }^{77}$ Bir başka ifadeyle,

74 İbn Kuteybe, el-İmâme, 1/142; İbnü'l-Esîr, el-Kâmil, 3/504; A. Cevdet Paşa, Kısas-ı Enbiyâ, 8/181; Seyithanoğlu vd., Doğuştan Günümüze, 2/307;

75 Süyûtî, Târîhu'l-Hulefâ, 233; İbnü'l-Esîr, el-Kâmil, 3/504. Bu husustaki bir başka rivayete göre o, siyasî zekâsını, dehâsını ortaya koyan şu konuşmasıyla Muâviye'yi hem memnun hem de ikna etmişti: “Yâ Emîre'l-mü'minîn! Yaşım ilerledi, kuvvetim azaldı, eskisi gibi iş yapamaz oldum; dünyaya dair de bir hacetim kalmadı. Üstlendiğim vazifeyi elimden geldiğince yapmaya çalışıı. Allah’tan, sana yardımım dokunmasından başka bir niyetim olmaz... Sizden sonra, oğlunuz Yezid'in halife olması için Kûfe eşrafını beyata davet ettim; onlar da icabet ettiler. Size danışmadan böyle bir işe kalkıştığımdan hoşlanmayacaksınız diye, size şimdi daha işin başında iken haber vermeye geldim. Bundan sonra dilerseniz beni görevden alın". Bu konuşma karşısında Muâviye, "Sübhânallah, Ey Ebû Abdurrahman! Şüphesizki Yezid, senin kardeşinin oğludur. Şimdi sen halkının başına dön ve başlattığın şeyi tamamla, işi hallet!” demişti. Rivayetin devamına göre ise Mugîre, Muâviye'nin yanından ayrıldıktan sonra şu ifadeyi kullanmıştı: "Öyle sağlam bir şey dikildi ki, bundan sonra onu yerinden ancak kan söker". (Ya‘kûbî, Târîh, 2/219-220).

Mugîre'nin çeşitli sebeplerle Yezid'in veliahtlik fikrini ortaya atarak kabul ettirmesi, bu konuda zikredilen rivayetlerin hem ihtilaflı hem de ittifak edilenlerden fazla oluşu, Mugîre'nin gençliğinden bu yana Resûlullah'ın dizinin dibinde yetişmiş bir sahabî olarak, bu yaptığıyla Müslümanlara verebileceği yıkıcı zararları düşünebilecek akıl ve kapasitede olduğu, dolayısıyla bu rivayetlere şüpheli bakılması gerektiği belirtilir. Bu konudaki görüşleri ve daha fazlası için bkz. Ömer Aktaş, "Muğîre b. Şû'be'nin Hayatı ve Kişiliği", Ağrn İslamîillimler Dergisi 2 (2018), 48-49.

76 Taberî, Târîh, 5/255; ibnü'l-Esîr, el-Kâmil, 3/326-327.

77 Kaynaklarda geçtiği gibi kısaca bunlar, Meysan'ı fethettiğinde, Hz. Ömer'e bu zaferi bildirdiği mektubu (Taberî, Târîh, 3/596); Sevad bölgesi valisi iken, Hz. Ömer'e bölgede, buğday ve arpa'ya nisbetle daha değerli ürünlerin olduğunu dolayısıyla bu konuda bazı yeni vergi uygulamalarına gidilebileceğini belirttiği mektubu (Belâzurî, Fütûh, 358; Mustafa Fayda, Hz. Ömer Zamaninda Gayr-ı Müslimler (İstanbul: Marmara Üniversitesi İlahiyat Fakültesi Vakfı Yayınları, 1989), 48; Seyithanoğlu vd., Doğuștan Günümüze, 2/130; 
Mugîre'nin, ne Ziyâd veya Muâviye gibi, hem biçim hem de içerik yönünden zengin yazı veya yazışmaları, ne de Amr gibi, gözlem ve deneyimlerini uzun uzun tasvirlerle anlattığı etkileyici mektuplarına rastlanmadığından, onun bu yönü müphem kalmaktadır.

\section{Ziyâd b. Ebîh ve Hitabet Yönü}

Rivayetlerin çoğuna göre Hicretin 1 . senesinde Taifte dünyaya gelen Ziyâd b. Ebîh, arkadaşı, mevkidaşı, selefi Mugîre b. Şu'be gibi Sakîf kabilesine mensuptur. ${ }^{78} \mathrm{Ba}-$ basının kimliği hakkındaki ihtilaftan dolayı "ibn Ebîh" şeklinde anılan Ziyâd, ${ }^{79} \mathrm{~Hz}$. Ebû Bekir döneminde Müslüman olmuş; Hz. Ömer döneminde Basra'nın kurucusu Utbe b. Gazvan tarafından buraya yerleştirildikten sonra, yaklaşık 15 yaşındayken, ganimetlerin muhasebesi ve taksiminden sorumlu tutulmak suretiyle devlet hizmetine alınmıştır. Bu andan itibaren sadece başarıyla yürüttüğü işiyle değil konuşmalarıyla da göz dolduran genç Ziyâd, halktan devletin en üst kademesindeki halifeye varıncaya dek birçok insanın da beğenisini kazanmıştır. ${ }^{80}$

$\mathrm{O}$, hem siyasî hayatının başladığı Hz. Ömer döneminde, hem de akabinde tecrübe birikimini arttırdığı Hz. Osman ve Hz. Ali dönemlerinde, her türlü muhasebe işlerinin ${ }^{81}$ yanı sıra vali kâtipliği ${ }^{82}$ ve vekilliği de yapmıștır. ${ }^{83}$ Bir süre sonra ise Hz. Ali

Muaviye'den sâdır olduğu izlenimini vererek yazdığı, kendisinin hac emirliği yapmasını sağlayan mektubudur; bk. Taberî, Târîh, 5/160; İbnü'l-Esîr, el-Kâmil, 3/402).

78 İbn Habîb el-Bağdâdî, Kitâbü'l-Muhabber, tsh. Ilse Lichtenstadler (Beyrut: Dârü'l-Âfâkı'l-Cedîde, ts.), 341; Dîneverî, el-Ahbâru't-Tivâl, 114; Zehebî, Siyeru alâm, 3/494; İbn Hacer, el-i̇sâbe, 2/43.

79 Zübeyrî, Nesebü Kureyş, tsh. E. Levi Provençal (Kahire: Dâru'l-Maârif, ts), 244; Mes'ûdî, Mürûc, 3/14-15; İbn Abdülber, el-ìstiâb, 2/525; İbn Hallikân, Vefeyât, 6/357.

Rivayetlere göre Ziyâd'ın annesi olduğu belirtilen Sümeyye, Taifli meşhur tabip Hâris b. Kelede'ye hediye edilmiş bir cariye idi. Keza babası olarak gösterilen Ubeyd de bu ailenin kölesi olup, birbirleriyle evlendirilmişlerdi. Buna göre Ziyâd -her ikisi de Rum diyarından getirilmiş olan- Ubeyd adlı bir köle ile Sümeyye adlı bir cariyenin izdivacı sürecinde doğmuştu. Ancak bazı rivayetlere göre Sümeyye, fuhuş ile iştigal eden -hatta Hâris b. Kelede'ye bundan dolayı para/vergi dahi ödeyen- bir kadın olup, Taif şehir merkezinden uzakta, onun gibi para kazanan başka kadınların olduğu bir mahallede yaşamaktaydı. İşte bu doğrultuda genel anlamda Ziyâd'ın babasının belirsizliğine atıf yapan; özel anlamda ise, onun babasının Ebû Süfyân olma ihtimaline zemin hazırlayan başka rivayetler daha karşımıza çıkmaktadır ki bunlara göre Ebû Süfyan, Taife yaptığı bir seyahat esnasında bu mahalleye uğramış, Sümeyye ile birlikte olmuş, Sümeyye de ondan hamile kalmıştı. Ancak bu sırada o Ubeyd'le evli olduğundan oğlu Ziyâd'ı kocası Ubeyd'in yatağında dünyaya getirmişti. Üstelik bazı rivayetlere göre Ebû Süfyân da bu ilişkiye işaret eden bazı itiraflarda bulunmuştu. Şöyle ki, Hz. Ömer zamanında daha ergenlik çağına yaklaştığı çok genç bir yaşta İran tarafındaki fetih ordusunda görev verilen ve rapor vermek üzere Hz. Ömer'e gönderilen Ziyâd, gerekli malumatı ve haberleri Halife'ye öyle etkileyici bir hitabetle anlatmışı ki, orada bulunan diğer insanlar gibi Ebû Süfyân da hayli etkilenmiş; hatta açıkça, Ziyâd'ı annesinin rahmine kendisinden başkasının yerleştirmediğini ifade etmişti. Bu konudaki geniş açıklama ve tartışmalar için ayrıca bk. Melek Yılmaz Gömbeyaz, Ziyâd b. Ebîh (Hayatt-Şahsiyeti-Devlet Adamliğı) (Bursa: Uludağ Üniversitesi, Sosyal Bilimler Enstitüsü, Doktora Tezi, 2015), 10 vd.

80 İbn Asâkir, Târîhu medîneti Dimaşk, 19/167; i̇bü̈'l-Esîr, el-Kâmil, 2/522; íbn Kesîr, el-Bidâye, 7/70.

81 İbn Kuteybe, el-Maârif, 151; Belâzürî, el-Ensâb, 5/198; Taberî, Târîhi, 4/543; İbn Asâkir, Târîhu medîneti Dtmašk, 19/170; İbnü'l-Esîr, el-Kâmil, 3/256.

82 Taberî, Târîh, 3/489; ibnü'l-Esîr, el-Kâmil, 3/453; ibn Kesîr, el-Bidâye, 7/36; Cevad Ali, el-Mufassal, 4/227.

83 Belâzürî, Fütûh, 498-499; Taberî, Târîh, 3/489; íbnü'l-Esîr, el-Kâmil, 3/123-124. 
tarafından vali sıfatıyla görevlendirilen Ziyâd, daha ilk valilik görevindeki başarılarıyla dikkatleri üzerine çekince, ${ }^{84}$ Muâviye tarafından kendi saflarına davet edilmişse de, o ancak Hz. Ali'nin vefatından sonra Mugîre ve Muâviye'nin gayretleriyle Muâviye'ye beyat etmiştir. ${ }^{85}$ Ziyâd'la kopmaz bağlar kurmak istediği anlaşılan Muâviye, mahkeme huzurunda onu aynı babadan olma kardeşi ilan etmiş, ${ }^{86}$ Ziyâd da onun yaptığı bu cömert yatırımın karş1lı̆̆ını, 53/673'te ${ }^{87}$ vefat edinceye dek yürüttüğü (Basra, Horasan, Sicistan, Hind, Bahreyn, Umman, Kûfe ${ }^{88}$ ) valilikleri süresince, yaptığı hizmetlerle fazlasıyla ödemiştir.

Ziyâd hakkında nakledilen rivayetler, onun sadece siyasî veya idarî alanlardaki dehâsından değil, aynı zamanda hitabetteki dehâsından, eşine az rastlanır hitabet kabiliyetinden de bahseder. Bu bağlamda onun, hitabet, ${ }^{89}$ fesahat $^{90}$ ve belagattaki üstünlüğünü, ${ }^{91}$ güzel sözleri kullanmada tam bir dehâ olduğunu ${ }^{92}$ ve "Hz. Ali'den sonra Ziyâd gibi bir hatip daha gelmediğini belirten rivayetler dikkate şayandir. ${ }^{93}$

Ziyâd, genç bir delikanlı iken üstlenmiş olduğu ilk resmî görevinde, fetihleri Hz. Ömer'e anlatmak üzere gönderildiğinde, anlatımıyla, Hz. Ömer'i etkilemeyi başarmış; o, "işte hatîb dediğin böyle olur" diyerek Ziyâd'ı takdir etmişti. ${ }^{94} \mathrm{~Hz}$ Ömer'in yanı sıra orada bulunanlar da bu gencin konuşmasını beğeniyle dinlemiş; hatta içlerinden Amr b. el-Âs ve Ebû Süfyân arasında şöyle bir diyalog geçmişti: Amr: "Yemin olsun ki, eğer bu çocuğun babası Kureyşli olsaydı, bu konuşma kabiliyetiyle bütün Arapları peşinden sürüklerdi”. Ebû Süfyân: Vallahi onu annesinin rahmine benden başkası yerleştirmedi". ${ }^{95}$

84 Belâzürî, el-Ensâb, 5/198; Taberî, Târîh, 5/137-138; ỉbnü'l-Cevzî, el-Muntazam, 5/159; ỉbn Kesîr, el-Bidâye, $7 / 321$.

85 Taberî, Târîh, 5/176-178; íbnü'l-Esîr, el-Kâmil, 3/422-423; ỉbn Kesîr, el-Bidâye, 7/24.

86 Belâzürî, el-Ensâb, 5/202; Dîneverî, el-Ahbâru't-Tivâl, 203; Zehebî, Siyeru a lâm, 3/494.

87 Ya'kûbî, Târîh, 2/229-230; Taberî, Târîh, 5/289; İbn Abdürabbih, el-Ikdül'-Ferîd, 5/274; İbn Abdülber, elİstîab, 2/530; İbnü'l-Esîr, el-Kâmil, 3/493-494.

88 Taberî, Târîh, 5/216; i̇bnü'l-Cevzî, el-Muntazam, 5/212; İbnü'l-Esîr, el-Kâmil, 3/448; ỉbn Kesîr, el-Bidâye, $8 / 28$.

89 İbnü'n-Nedim, el-Fihrist, thk. Ruza Teceddüd (Tahran: y.y., 1971), 139; İbn Abdülber, el-İstîâb, 2/523; íbn Hallikân, Vefeyât, 6/356; Kütübî, Fevât, 2/32; Ömer Ferruh, Târîhu'l-edebi'l-Arabî, 4. Bs. (Beyrut: Dârü'l-Illm li'l-Melâyin, 1981), 1/388.

90 Kütübî, Fevât, 2/32; A. Cevdet Paşa, Kısas-ı Enbiyâ, 8/619; Ferruh, Târîhu'l-edebil'-Arabî, 1/388.

91 Belâzürî, el-Ensâb, 5/199; i̇bn Hallikân, Vefeyât, 6/356.

92 Taberî, Târîh, 5/221.

93 Ebü'l-Fidâ, Târîhu Ebîl'-Fidâ (=el-Muhtasar fi ahbâri'l-beşer), thk. Mahmûd Deyyûb (Beyrut: Dârü'l-Kütübi'lİlmiyye, 1997), 1/258.

94 İbn Asâkir, Târîhu medîneti Dimaşk, 19/167; ỉbnü'l-Esîr, el-Kâmil, 2/522; ỉbn Kesîr, el-Bidâye, 7/70.

95 İbn Asâkir, Târîhu medîneti Dımaşk, 19/175; İbnü'l-Esîr, el-Kâmil, 3/443. Bir başka rivayete göre Ziyâd, sorumlu olduğu işlerle ilgili bilgileri rapor etmek üzere Hz. Ömer'e gitmiş; yıl içerisinde ne kadar harcama yapıldığını, geriye ne kaldığını ve gelir-giderlerin miktarıı rakamlarla sıralayınca, insanlar onun hitabetinin yanı sıra zekâ ve hafizasına da hayran kalmış; Hz. Ömer de Ziyâd'a bin dirhem verilmesini emretmişti. Belâzürî, elEnsâb, 5/198. 
Şüphesiz ki, Ziyâd b. Ebîh ve hitabet kelimeleri bir araya geldiğinde akla gelen ilk şey, kaynaklarda ifade edildiği şekliyle "Betrâ" ${ }^{96}$ veya Büteyrâ" ${ }^{97}$ adıyla anılan ${ }^{98}$ Basra hutbesidir. Tahmîdsiz ${ }^{99}$ ve temcîdsiz ${ }^{100}$ başlamass ${ }^{101}$ ve bu açıdan bir ilk olmas1 ${ }^{102}$ bir yana, edebî yönünün kuvvetliliği nedeniyle de kaynaklarda ayrı bir yeri olan bu hutbe, ${ }^{103}$ "şaheser" 104 veya "edebî hazine" ${ }^{105}$ gibi ifadelerle nitelendirilmiş; onun, lafızları fasîh, terkîbleri açı, üslûbu veciz ve sağlam, aynı zamanda akıcı bir dilin ve hazır bir zihnin ürünü olduğu belirtilmiştir. ${ }^{106}$

Siyasî, ictimaî, dinî, hukukî vs. hemen her yönden bir toplumun fotoğrafının çekildiği hutbe, aynı zamanda o döneme dair kapsamlı malumat içeren bir belge değerindedir. Hutbe, toplumsal açıdan gelinen vahim durumun etkisiyle hayli uzun olup genel anlamda sert bir üslup taşımakla birlikte, muhatap kitleyi kuşatması, akıcılı̆̆ı, edebî sanatlar gibi diğer zengin özellikleri ile karsısındakini içine çekmektedir. Ayrıca cümlelerinde, hedef kitle ve onların icraatlarına binaen, yeri geldiğinde nasihat, vaad, ikaz; yeri geldiğinde de tehdit, vaîd, meydan okuma gibi yönleriyle öne çlkan hutbe, geçmiş, bugün ve geleceğe dair mesajlarıyla da dikkat çekicidir.

Şunu da belirtmek gerekir ki, her ne kadar Ziyâd'ın daha meşhur hutbeleri genellikle Muâviye dönemine tekabül etse de onun çok daha öncesinde gerek Hz. Ömer döneminde halifenin ve halkın huzurunda yaptığı, gerekse Hz. Ali'nin valisi olarak Muâviye'nin tehditlerine karşılık verdiği hutbeler de hayli etkili ve etkileyici olmuştur. ${ }^{107}$

96 Betrâ kelimesi, “بّ” kökünden gelmekte olup kopuk, kesik, tamamlanmamış, kısır, kurumuş, hayrı kalmamış gibi anlamlarının yanısıra, Ziyâd'ın Basra'daki hutbesi gibi, Allah'a hamd ve Peygamber'e salât ile başlamayan (bkz. İbn Manzûr, Lisânül'-Arab, 1/309) keza besmelesiz yani Allah'in adı zikredilmeksizin başlanan hutbelere verilen isimdir; bkz. Nüveyrî, Nihâyetül-ereb, 20/193.

97 İbn Asâkir, Târîhu medîneti Drmașk, 19/179.

98 Câhız, el-Beyân, $2 / 6$.

99 Taberî, Târîh, 5/217; íbn Abdürabbih, el-ikdü'l-ferîd, 4/199; íbnü'l-Esîr, el-Kâmil, 3/447; Nüveyrî, Nihâyetüllereb, 20/193.

${ }^{100}$ Câhiz, el-Beyân, 2/6, 62; ỉbn Kuteybe, Uyûnü'l-Ahbâr, 2/241; ỉbn Abdürabbih, el-ikkdül-ferîd, 4/199; ỉbn Manzûr, Lisânü'l-Arab, 1/309.

101 Bu rivayetin aksine Ziyâd'ın, usulsüz bir şekilde değil, Allah'a hamd ü senâ eyledikten sonra konuşmasına başladığı da kaydedilir; bkz. Câhiz, el-Beyân, 2/62; Belâzürî, Ensâbül'-Eşrâf, 5/198; Dîneverî, el-Ahbâru't-ttvâl, 203; Taberî, Târîh, 5/217; ìbn Abdürabbih, el-ìkdül-ferîd, 4/119; i̇bnü'l-Esîr, el-Kâmil, 3/447; Nüveyrî, Nihâyetül'-ereb, 20/193.

102 İbn Kuteybe, Uyûnül-Ahbâr, 2/241.

${ }^{103}$ Ziyâd'ın hutbesine hamdele ve salvelesiz başladığı rivayetler düşünüldüğünde, onun bununla, dikkatleri şimşek gibi üzerine çekmek, söyleyeceklerinde ne kadar ciddi olduğunu göstermek veya artık hiçbir şeyin eskisi gibi olmayacağını işaret etmek üzere, bir nevi insanlarda şok etkisi yaratmak amacı taşıyabileceği düşüncesi de akla gelmektedir. Hutbenin değerlendirmesi için bkz. Gömbeyaz, Ziyâd b. Ebîh, 133 vd.

${ }^{104}$ Isaac Hasson, "Ziyād b. Abīhi", The Encyclopaedia of Islam Second Edition (Leiden: Brill, 2002), 11/520.

${ }^{105}$ Philip K. Hitti, Siyasî ve Kültürel İslam Tarihi, çev. Salih Tuğ (İstanbul: Boğaziçi Yayınları, 1980), 2/391.

${ }^{106}$ Ferruh, Târîhu'l-edebil'-Arabî, 1/388.

${ }^{107}$ Ahmed Zeki Safvet, Cemheratü hutabi'-Arab fîusuri'l-Arabiyyeti'z-zâhire (Kahire: Mustafa el-Bâbî el-Halebî, 1933), 2/253-254. 
Rivayetlere bakıldığında, Ziyâd'ın, konuşmaları kadar yazılarında da etkileyici, edebî ve zengin bir üslup sahibi olduğu karşımıza çıkar ki bunlar ana hatlarıyla, şahsî veya resmî mektupları ile tevkîâtı (mektup, dilekçe veya resmî yazıların kenarlarına düşülen özlü söz ve notlar)dır. Konuşmalarındaki dil ve edebiyat zenginliğinin aynı güzellikte yansıdığı görülen bu yazılarında da Ziyâd benzer şekilde ayet-i kerime, hadis-i şerif, darb-1 mesel, teşbîh veya tasvîr gibi çeşitli unsurlarla cümlelerinin gücünü arttırmıştır. ${ }^{108}$ Son olarak, ${ }^{109}$

Hz. Ali'den sonra en iyi hatip olarak gösterilen, ${ }^{110}$ dile son derece hâkim, ender rastlanan bir kelime ustası, ${ }^{111}$ konuştukça konuşması güzelleşen ve kendini dinleten bir hatip olarak değerlendirilen ${ }^{112}$ Ziyâd'ın veciz sözlerinden birkaçını da onun hitaplarına dair fikir sunması açısından aktarmak yerinde olacaktır: "İnsan için dünyada nasibi kadarı vardır; fazlası değil."113 “Tehirdeki hayır, tecildeki şerden daha evladır." "Dünyâ dâr-1 zevâldir; onda beka aranmaz."115

Mana bakımından hem dünya hem de ahiret hayatına yönelik öz ve derin nasihat nevinde mesajlar içeren bu sözler, en az manaları kadar lafız/ifade yönünden de yüksek değere sahip sözler olarak kaynaklarda yerini almış örneklerden sadece birkaçıdır.

\section{Muâviye b. Ebî Süfyân ve Hitabet Yönü}

Emevî Devleti'nin kurucusu olan Muâviye b. Ebî Süfyân, 602 veya 603 yılında Mekke'de doğmuş olup ${ }^{116}$, annesi Hind bint Utbe, babası ise Ebû Süfyân b. Harb'dir. ${ }^{117}$ Hem anne hem de baba tarafından şehrin önde gelen ailelerine mensup olan Muâviye, zengin bir sosyal, kültürel ve siyasî çevrede büyüdükten sonra, büyük ihtimalle Mekke'nin fethi esnasında Müslüman olmuştur. ${ }^{118}$

Hz. Peygamber (s.a.v.) döneminde kâtipliğin yanı sıra askerî vazifelerde bulunan Muâviye, Hz. Ömer zamanında ise Ürdün ve daha sonra Dımaşk valiliğine atanmıştır. ${ }^{119}$

${ }^{108}$ İbn Sa'd, et-Tabakât, 4/218; Belâzürî, el-Ensâb, 5/255, 288-289; Taberî, Târîh, 5/168, 256; ỉbn Abdürabbih, el-ikkdül'-ferîd, 4/299-300; İbnü'l-Esîr, el-Kâmil, 3/415, 473; Safvet, Cemherat, 2/263.

109 Dört Arap dâhisi arasında Ziyâd'ın hatip kimliğine dair söylenmesi gereken birçok husus ve ele alınması icap eden pek çok örnek bulunmaktadır. Bunların burada verilmesi hem makalenin hacmini kabartacağından hem de diğer üç dâhiye ayrılan kısımlara nazaran orantısız duracağından Ziyâd'ın hitabet yönünün müstakil bir makale çerçevesinde incelenmesi daha uygun görülmüş ve bu nedenle burada öz bir şekilde verilen malumatın detayları ve ilave hususlar bir başka makale çalışmamızda incelenmiştir. Bu çalışma için bkz. Melek Yılmaz Gömbeyaz, "Erken Dönem İslam Tarihinde Hitabetiyle Öne Çıkan Bir Siyasî: Ziyâd b. Ebîh", Ihyya Uluslararası İslam Araştırmaları Dergisi 6/2 (Temmuz 2020), 711-733.

${ }^{110}$ Ebu'l-Fidâ, Târîh, 1/258.

${ }^{111}$ Şevki Dayf, Târîhu'l-edebi'-Arabî̀ el-Asru'l-̇̇slâmî (Kahire: Dâru'l-Maârif, 1992), 424.

112 Taberî, Târîh, 5/221; Zehebî, Siyeru a lâm, 3/494; Dayf, el-Asru'l-İslâmî, 424.

113 Belâzürî, el-Ensâb, 5/288-289; ỉbn Asâkir, Târîhu medîneti Dimașk, 19/205-206.

114 Taberî, Târîh, 5/302; İbnü'l-Cevzî, el-Muntazam, 5/285-286; İbnü'l-Esîr, el-Kâmil, 3/505; Nüveyrî, Nihâyetülereb, 20/219-220.

115 Belâzürî, el-Ensâb, 5/288-289; ỉbn Asâkir, Târîhu medîneti Dımașk, 19/205-206.

116 İbn Kuteybe, el-Maârif, 350; Ya'kûbî, Târîh, 2/212; Zehebî, Siyeru alâm, 3/161-162.

117 İbn Sa'd, et-Tabakât, 6/15; Taberî, Târîh, 5/328; Zehebî, Siyeru alâm, 3/161.

118 İbn Kuteybe, el-Maârif, 350; İbn Abdülber, el-Istîâb, 3/395.

119 İbn A'sem el-Kûfî, el-Fütûh, thk. Ali şî̂î (Beyrut, ts.) 1/263; Taberî, Târîh, 4/102. 
Hz. Osman tarafından Suriye bölge valiliğine getirilen Muâviye, bu dönemde bir vali olarak kazanabileceği kadar güç ve tecrübe kazandı. Hz. Osman'ın şehadetinin ardından da -tüm bu gücün boşa gitmesine izin vermeyeceğinden, çeşitli sebeplerle Hz. Ali'ye beyat etmedi. Arkasında, sırtını yasladı̆̆ı Şam halkı, dilinde "Hz. Osman'ın hakkı" ile Muâviye, tebaası kendisine sahip çıkmakta ihtilafa düşmüş bir Halife'ye karşı mücadeleye girişmek üzere Şam halkının beyatını aldı. Bundan sonra, Hz. Ali'nin tekraren yaptığı beyat çağrılarını reddedince taraflar sıffîn'de karşı karşıya gelmek durumunda kaldı. Yenilmek üzere olan Muâviye, Amr b. el-Âs'ın savaşın durmasına sebep olan teklifi sayesinde, mağlubiyetten galibiyet çıkarmayı başardı. Böylelikle o, gözüne kestirdiği dâhi isimleri kadrosuna katmasının karşılığını çok erken zamanlarda, daha halife olmadan almaya başladı. 660/680 senesinde Hz. Ali'nin şehit edilmesinin ardından oğlu Hz. Hasan'a beyat edilse de bir süre sonra Muâviye hilafeti ondan devralmak suretiyle resmen halife oldu.

Hilafeti boyunca başta Şia ve Haricîler olmak üzere birçok iç meseleyle uğraşmak durumunda kalan Muâviye, sorunlu bölgeleri, Amr, Mugîre, Ziyâd gibi Dühât-1 Arab'in yetenekli, ehil isimlerine havale etmek suretiyle buraları kontrol altında tutmayı başarmıştı. ${ }^{120}$ Yaklaşık 20 yıllık iktidarının sonlarına doğru ise, oğlu Yezid'i veliaht tayin etmek suretiyle yeni bir dönem başlatmış ${ }^{121}$; böylece, Muâviye'nin 60/680 senesinde vefat etmesinin ${ }^{122}$ ardindan devlet hanedan sistemiyle yönetilir olmuştur.

Muâviye b. Ebî Süfyân, dehâsı, sabrı, hilmi ve ileri görüşlülüğü ile ender yetişen bir diplomat, insanlara anlayacakları dilden konuşarak yaklaşmayı bilen bir idareci idi. ${ }^{123} \mathrm{O}$, konuşmayı problem çözme yollarından biri olarak görür; konuşmanın iş gördüğü yerde kırbaca gerek olmadığını, ${ }^{124}$ diliyle, kılıçla kazanılandan çok daha fazlasını kazandığını söylerdi. ${ }^{125}$ Muâviye'nin, gerek çocukluğunda aldığı eğitim ve yetiştiği ortam, gerekse idarecilik yıllarında âlimler, şairler, edipler ve tarihçilerle sohbet etmeyi alışkanlık haline getirmiş olması hasebiyle hitabet yönünden birçok kazanım elde etmiş olduğu muhakkaktır. Bu bağlamda, sahip olduğu hitabet gücü, muhatabını etkileyebilmesi ve kime nasıl konuşacağını iyi seçmesi, Muâviye'nin hemen her dönemde hedeflerine ulaşmasını sağlayan etkenlerden olmuştur. ${ }^{126}$

\footnotetext{
120 Melek Y1lmaz Gömbeyaz, “Muaviye b. Ebî Süfyân'ın Muhaliflerini Bertaraf Etme Yöntemleri”, Uludă̆ Üniversitesi İlahiyat Fakültesi Dergisi 19/1 (2010), 307.

121 İbn Kuteybe, el-Maârif, 350; Taberî, Târîh, 5/322 vd.

122 İbn Kuteybe, el-Maârif, 350; Ya‘kûbî, Târîh, 2/212; İbn Abdürabbih, el-íkdü'l-Ferîd, 118; Zehebî, Siyeru alâm, 3/161-162.

123 İrfan Aycan, "Muâviye b. Ebû Süfyân”, Türkiye Diyanet Vakfi İslâm Ansiklopedisi (İstanbul: Türkiye Diyanet Vakfi Yayınları, 2005), 30/334.

124 İbn Kuteybe, Uyûnü'l-Ahbâr, 1/63; Ya'kûbî, Târîh, 2/238; İbn Abdürabbih, el-İkdü'l-Ferîd, 1/25.

125 İbn Kuteybe, Uyûnül-Ahbâr, 1/63.

126 Aycan, Muâviye Bin Ebî Süfyân, 48, 51.
} 
Muâviye'nin hitaplarına genel anlamda bakıldığında, iyi bir gözlem, kararlılık ve sonuç odaklı ifadeler göze çarpar ki, buna ilk örnek olarak, onun Hz. Ali ile kendisini kıyaslamak suretiyle durumları hakkında değerlendirmeler yaptığı şu rivayeti aktarmak mümkündür:

Ben Ali karşısında dört konuda daha şanslıydım. Ben sırrımı/planlarımı saklardım, o anlatırdı. Benim sağlam ve itaatkâr bir ordum vardı, onun ordusu ise bozuk ve asi idi. Ben onu Cemel ashabına bırakmıştım; şayet Cemel ashabı onu yenerse zaten onlar bana Ali'den daha yeğdir; eğer Ali onları yenerse ben de onu (savaşı) Ali hakkında kullanırım. Ayrıca Ali'ye nazaran ben Kureyş'in nezdinde daha sevimliydim. Ali'den ayrılıp bende birleșenlere ne mutlu! ${ }^{127}$

Muâviye'nin hitabet gücünü gösteren bir diğer konuşması, daha erken bir döneme ait güzel bir örnektir. Buna göre Hz. Osman, şehrin huzurunu bozdukları gerekçesiyle bazı kimseleri Muâviye'nin kontrolündeki Şam'a sürgüne gönderdiğinde, Muâviye onları, tehditle karışı nasihat içeren bir üslupla uyararak şunları söylemişti:

"Siz, Araplardan bir kavim idiniz, dişleriniz ve dilleriniz vardı (en ilkel halde/cahiliye döneminde idiniz). Sonra İslâm'la şereflendiniz ve diğer ümmetlere üstün geldiniz, onların miraslarına sahip oldunuz. Öğrendiğime göre, Kureyş’ten intikam alma arzusuna kapılmışsınız ki, oysa Kureyş olmasaydı daha önce olduğunuz gibi zillet içinde olurdunuz. Şüphesiz ki, imamlarınız (yöneticileriniz) sizin kalkanınızdır; o halde kalkanınızdan ayrılmayınız. (Bilin ki) imamlarınız size karşı zor kullanmamak için sabrediyor ve tahammül gösteriyorlar. Vallahi ya bu işten vazgeçersiniz ya da Allah size gerçekten kötü davranacak ve sabır göstermeyecek birini musallat eder. (Böylelikle) siz de hem sağlı̆ınızda hem de öldükten sonra, halka zulmetme noktasında onların ortakları sayılırsınız..."

Karşılıklı atışma ve restleşmelerle süren bu konuşmalar esnasında Muâviye hem kendini hem de Kureyş’i uzun uzun övmekten de geri durmamıștı. Hatta son cümlelerinde;

... Bütün insanlar Ebû Süfyân'dan (onun sulbünden) doğmuş olsaydı, hiçbir tanesi ahmak olmazdı" dedikten sonra, aynı kararlılıkla vazifesine devam edeceğini ve onlar gibilere firsat vermeyeceğini şu sözleriyle belirtmişti: “... Aman ha, böyle işlerde Şeytan hep bir şeyler söyler, emirler verir. Hayatım üzerine yemin ederim ki, eğer işler sizin görüş ve arzularınıza göre gerçekleştirilseydi, ehl-i İslâm için bir gün veya bir gece bile doğru-düzgün gitmezdi... Eğer siz, korktuğum gibi, Şeytana uyar da Rahmân'a isyan etmeyi sürdürürseniz, bu sizi er ya da geç/hem dünyada hem de ahirette zelil kllar. ${ }^{128}$

Hz. Osman döneminde muhalifleriyle yaptığı uzun soluklu konuşmalar Muâviye'nin hitabet üslubunun açık ve açıklayıcı örneklerinden olmuştur. Rivayetlerden anlaşıldığına göre onun hitapları, ne -Ziyâd'ınkilerde olduğu gibi- göz alıcı

127 İbn Abdürabbih, el-íkdül-Ferîd, 5/115.

128 İbn A'sem, el-Fütûh, 1/386; Taberî,Târîh, 4/319 vd.; İbnü'l-Esîr, el-Kâmil, 3/32 vd. 
edebî parçaların, sanatsal ögelerin; ne -Amr'ınkilerde olduğu gibi- uzun betimlemeler veya teşbihlerin; ne de -Mugîre'ninkilerde olduğu gibi- genellikle 1lımlı seyreden bir yaklaşım ve üslubun ağır bastığı/yoğunlukta olduğu tarzda değil; daha çok, ileti/iletişim odaklı veya problemi ortaya koyarak onu çözmeye yönelik siyasî amaca hizmet eden, nasihat, uyarı ve tehdit ağırlıklı konuşmalar görünümündedir.

Elbette Muâviye de iyi bir hatip olarak, ayet ve hadislerin gücüne başvurmuş, ${ }^{129}$ yanı sıra konuşmalarının can alıcı noktalarında yemin ifadeleri kullanmayı da ihmal etmeyerek muhataplarını etkilemede onlardan istifade etmiştir. Ayrıca Muâviye'nin üslubunda, göze çarpar şekilde -“ma'siyyetü'-Rahmân-mütâva'atü'şŞeytân" (Allah'a isyan-Şeytan'a itaat) ${ }^{130}$ ifadesinde kullandığı gibi veya aşağıdaki rivayette de görüleceği üzere- seçmiş olduğu (lafzen uyumlu manen karşıt) kelimelerin oluşturduğu zıtlıkların getirdiği hoş bir uyum ve akışın da olduğu, bunun da hitabeti derinleştirdiği görülebilir.

Bu noktada, Muâviye'nin vefatına yakın zamanlarda yaptığı konuşmaların -aşağıdaki örneklerde görüleceği üzere- hemen her biri Muâviye'nin hitabet kabiliyetine delalet eder niteliktedir ki, onlardan biri şöyledir:

"Ben şu an hasat yapmak üzere olan çiftçiler gibiyim. Üzerinizdeki emirliğim hayli uzun oldu; öyle ki ben sizden bıktım, siz de benden bıktınız; ben sizden ayrılmak istedim, siz de benden ayrilmak istediniz. (Ancak bilin ki) Size benden sonra gelecek olan (idareci) benden daha hayırlı olmayacak; tıpkı benim benden öncekilerden hayırlı olmadığım gibi... Denildiğine göre, Allah’a kavuşmayı isteyen kişiye Allah da kavuşmak istermiş. Ey Allah'ım! Ben sana kavuşmak istiyorum; sen de bana kavuşmayı iste."131

Muâviye'nin, kimi zaman ibret ve hikmet, kimi zaman da itiraf ve istiğfar kokan, ama özellikle şiire olan düşkünlüğünün ön plana çıktığı ve ancak az bir kısmını aktarmak durumunda olduğumuz bu konuşmalarından birinde o, şu meşhur beyitleri okumuştu:

Ben öldüğümde cömertlik de ölür ve (onlara akıtılan musluk) kesilir

İnsanlardan, ancak az bir bölümü müstesnâ.

İsteyenlerin elleri boş geri çevrilir,

Dinden de dünyadan bir şey vermezler onlara. ${ }^{132}$

Yine vefatına yakın hastalandığında buna sevinerek kendisini görmeye gelenler hakkında şu meşhur beyitlerle konuşmuştu:

Benim süslenmem (dinç görünmem), göstermektir

Onlara, zamanın hilelerinin beni yıkamadığını

Ve ölüm pençelerini çıkardığında,

Anlarsın hiçbir üfürüğün faydalı olmadığını. ${ }^{133}$

129 Taberî, Târîh, 4/319 vd.; İbnü'l-Esîr, el-Kâmil, 3/32 vd.

130 Taberî, Târîh, 4/325.; İbnü'l-Esîr, el-Kâmil, 3/35.

131 İbnü'l-Esîr, el-Kâmil, 3/368.

132 Taberî, Târîh, 5/327; İbnü'l-Esîr, el-Kâmil, 3/369-370.

133 Taberî, Târîh, 5/326-327; İbnü'l-Esîr, el-Kâmil, 3/369. 
Ayrıca sevinçle onun ölümünü bekleyenler olduğunu işitince de şu beyti okumuştu:

Biz öleceksek, sanki dünyada ebedî kalacak var mıdır?

Ve ölüm, ey insanlar, bir utanç mıdır? ${ }^{134}$

Muâviye vefatı iyice yaklaştığında ise kızının kollarında iken dilinden şu mısralar dökülüvermişti:

İnceden inceye beni hesaba çekersen yâ Rab,

Benim (bu) azaba dayanacak mecalim yoktur

Ya da affedersen ki Sen felâha çıkaran Rabsin

Kum gibi günahları olsa da kötülük edenin. ${ }^{135}$

Muâviye'nin, sözlü hitabette sergilediği yeteneğini, benzer şekilde yazılı hitabette de gösterdiğini; bir başka ifadeyle başta mektupları olmak üzere yazılarında da fasih, beliğ ve akıcı bir üslup ortaya koyduğunu, yanı sıra konuşmalarındaki ikaz, nasihat, vaad, vaîd, tehdit gibi hâkim unsurların dozlarını daha yüksek tuttuğunu görmek mümkündür. Bu anlamda, Muaviye'nin, henüz kendisine beyat etmemiş olduğu dönemlerde Ziyâd'ı sindirmek için ona gönderdiği mektuplardan biri hayli etkileyici bir örnektir:

Dün köle idin, bugün emir (oldun)! Eşsiz bir sıçrama/yükseliş gerçekleştirdin ey İbn Sümeyye! Bu mektubum sana ulaştığında, halkınla birlikte beyat et; davetime icabette de acele et; zira ancak bu şekilde kanını akıtmam ve sen de (böylece) kendini kurtarmış olursun! Yok, eğer (dediklerimi) yapmazsan, seni aşağılık bir halde yakalatır, Fâris'ten Şam'a korku içinde getirtir, sokaklarda (ibret olsun diye) dolaştırır, bir köle olarak satarım ve böylece seni geldiğin yere/çıktığın o deliğe geri gönderirim. ${ }^{136}$

Muaviye'nin, iletişim dilini her türlü kullanmayı bilen bir siyasetçi olarak, Ziyâd'la bu üslupla anlaşamayacağını anlayınca bu kez ona iltifat eden, alttan alan, onu güç birliğine davet eden hatta baba bir kardeş olduklarını ilan etmeye dahi hazır olduğunu gösteren vaadler içeren şu mektubu da zikre şayan örneklerden biridir:

Müminlerin emiri Muaviye b. Ebî Süfyan'dan Ziyâd b. Ebî Süfyan'a... Bana karşı olan sû-i zannın ve buğzun, seni, benimle olan akrabalık -bağını- koparmaya, yakınlı̆̆ımı (kan bağımı), nesebimi ve saygınlığımı reddetmeye sevk etti. Sanki sen benim kardeşim değilsin; sanki Sahr b. Harb ikimizin de babası (atası) değil. Eğer benim yanımı ister ve bana güvenirsen, işte sana emirlik (emirlikse emirlik); yok eğer benim yanımı istemez ve sözüme güvenmezsen, bu da güzel bir iştir; ne aleyhime ne de lehimedir, (canın sağ olsun) vesselam. ${ }^{137}$

134 ìbnü'l-Esîr, el-Kâmil, 3/370.

135 Taberî, Târîh, 5/326; i̇bnü'l-Esîr, el-Kâmil, 3/ 370.

136 İbnül'-Esîr, el-Kâmil, 3/352-354.

137 Safvet, Cemhera, 2/254. Nitekim ileriki yıllarda Muâviye ve Ziyâd mescitte şahitler getirmek suretiyle, Ebû Süfyân'ın (Câhiliyye döneminde) Ziyâd'ın annesi Sümeyye ile birlikte olduğunu ve Ziyâd'ın da bu ilişkiden meydana geldiğini ve dahi Ebû Süfyân'ın da -aralarında Hz. Ali ve Amr b. el-Âs'ın da bulunduğubir topluluk içinde zaten bunu itiraf ettiğini; dolayısıyla bu hadisenin bilinen/çok da gizli kalmayan bir hadise olduğunu gözler önüne sermek suretiyle halkın huzurunda mahkeme gerçekleştirdiler. Neticede 
Muâviye'nin oğlu Yezid'e verilmek üzere yazdığı vasiyeti ise, başta siyasî olmak üzere, tarihî, sosyolojik, psikolojik vb. gibi birçok alanda görüş veya tecrübe aktaran; insan ilişkilerine dair önemli tavsiyeler sunan, ögütler içeren bir metin halindedir:

Oğlum, senin önüne çıkacak zorluk ve problemleri kaldırdım, düşmanlarını bertaraf ettim, Arapları itaat altına aldım, senin için hiç kimsenin yapamayacağı kadar servet biriktirdim. (Bundan sonra) Hicaz halkına dikkat et; onlar senin büyüklerindir. Onlardan yanına gelenlere ikramda bulun, gelmeyenlerle de iyi ilişkiler kur. Iraklılar'a gelince, eğer senden her gün bir vali değiştirmeni isteseler bile kabul et; zira bunu yapman yüz bin kılıcın çekilip üstüne gelmesinden daha iyidir. Suriye Araplarını ise sırdaşın edin; düşmanlarından gelen zararı onlarla bertaraf edersin. Sonrasında ise onları tekrar memleketlerine gönder; çünkü başka yerde kalırlarsa ahlâkları değiş̧ir (bu da bizim için hiç iyi olmaz). Senin (halifeliğin) hususunda şu üç kişiden başka hiçbir Kureyşli'den korkmuyorum; bu kişiler Hüseyin b. Ali, Abdullah b. Ömer ve Abdullah b. Zübeyr'dir. Abdullah $b$. Ömer, ibadete düşkün olup (böyle işlerle uğraşamaz) senin önüne çıkmaz. Hüseyin b. Ali ise -ki Allah onun babasını öldürmüş, kardeşini de yüzüstü bırakmıştı- hafif (üstesinden gelebileceğin) bir kimsedir. O, Hz. Muhammed aleyhisselamın yakın akrabası olup (böyle) büyük bir hakkı/konumu vardır. Ancak Iraklıların onu sana isyan edene dek rahat bırakacağını zannetmiyorum. Bu gerçekleşir de, sen de onu yenersen kendisini affet; ben olsam böyle yapardım. Son olarak İbn Zübeyr'e gelince, sana bir aslan gibi saldırıp tilki gibi tuzak kuracak tek kişi odur. Şayet sana karşı böyle şeylere girişecek olursa onun hakkından gel ve (bunu yaparken de) elinden geldiği kadar kendi kavminin/adamlarının kanının akmasına izin verme. ${ }^{138}$

Son olarak, akıllı, zeki, bilgili, hakîm, fasîh ve belîğ bir kişi olarak görülen Muâviye'nin ${ }^{139}$ söz konusu özelliklerini temsil eden bazı veciz sözlerini aktarmak suretiyle konuyu tamamlamak faydalı olacaktır:

“Insanlarla aramda asla koparmadığım bir ip/bağ vardır. Onlar (ona) asıldıklarında ben gevşetirim; onlar (onu) gevşettiklerinde ise ben asılırım."

"Bizimle mülkümüz arasına girmedikleri sürece, insanlarla dilleri arasına girmem."141

"Paranın iş gördüğü yerde konuşmaya, konuşmanın iş gördüğü yerde kırbaca, kırbacın iş gördügü yerde de kılıca lüzum yoktur."142

Muâviye Ziyâd'ı kendi -babasının- nesebine katarak onun artık resmen "İbn Ebî Süfyân” olduğunu ve öyle anılmasını emretti. O günden sonra her ikisi de bu kararın arkasında durup takipçisi olmuş; eski veya aksi hitap şekillerine izin vermeyerek bunu yapanlarla mücadele etmişlerdir. Geniş malumat ve izahat için bk. Melek Yılmaz Gömbeyaz, Ziyâd b. Ebîh (Hayatı-Şahsiyeti-Devlet Adamlı̆̆ı) (Bursa: Uludağ Üniversitesi, Sosyal Bilimler Enstitüsü, Doktora Tezi, 2015), 85 vd.

138 Taberî, Târîh, 5/323; İbnü'l-Esîr, el-Kâmil, 3/369; İbn Abdürabbih, el-íkdü'l-Ferîd, 5/123.

139 Hasan, İslâm Tarihi, 1/360.

140 İbn Abdürabbih, el-ìkdü'l-ferîd, 1/25.

141 Taberî, Târîh, 5/336; İbnü'l-Esîr, el-Kâmil, 3/366.

${ }^{142}$ Ya'kûbî, Târîh, 2/238; İbn Abdürabbih, el-íkdü'l-Ferîd, 1/25. 
"Affımdan daha büyük bir suç, hilmimden daha büyük bir cehalet veya örtümle üstünü örtemeyeceğim bir ayıp ya da ihsanımdan daha çok olan bir kötülük (olsun istemem)..."143

"Akıllı kişi, sonunda pişmanlık duyacağı işe kalkışmayandır."144

“Akıl ve hilim, bir kula verilen en faziletli şeylerdir. (Bunlara sahip olan kişiye) nasihat edildiğinde dinler, bir şey verildiğinde şükreder, musibete uğradığında sabreder, öfkelendiğinde kendine hâkim olur, kudret sahibi olduğunda affeder, bir kötülük işlediğinde af diler, söz verdiği zaman yerine getirir."145

"İnsanların en sabırlısı, fikir ve görüşlerini, duygu ve arzularına feda etmeyendir."146

İnsana çok yönlü hayat dersleri sunan, zengin mana ve lafizlarla mücehhez olan bu cümlelerin, anlayan veya muhatap alanlar için, çoğunlukla tecrübe edilerek aktarılmış, özel, sosyal veya siyasî hayata dair evrensel denebilecek ilke niteliğinde telkin ve tavsiyeler içeren veciz sözler olduğunu söylemek yanlış olmayacaktır.

\section{Sonuç}

Tarihte Arabın dâhileri olarak bilinen Amr b. el-Âs, Mugîre b. Şu'be, Ziyâd b. Ebîh ve Muâviye b. Ebî Süfyân, sadece siyasetteki maharetleri değil aynı zamanda hitabetteki kabiliyetleriyle de öne çıkmışlardır. Tıpkı dehâları gibi hitabetleriyle de devletin en üst kademelerinde muhkem yerler edinmekte zorlanmayan bu isimler, sadece icraatlarıyla değil hitabetleriyle de idarelerini şekillendirmiş, otoritelerini güçlendirmişlerdir.

Benzer ve farklı yönleri olmakla birlikte "iyi birer hatip" olarak gösterilen dühât-1 Arabdan Mugîre daha ziyade ikna edici cümleleri; Amr sade, uzun ama akıcı tasvirleri; Ziyâd gerek dil ve üslup hâkimiyeti gerekse edebî zenginlik yönünden üstünlüğü; Muâviye de vurgulu, etkili ve bir o kadar da etkileyici tarzı ile dikkat çekmektedir. İkaz, tehdit, nasihat, malumat, izahat, talimat gibi birçok saik veya ana fikir içeren bu hutbeler, fesâhat, belâgat, edebî sanat gibi unsurlarla güçlendikçe muhatabı üzerindeki kuşatıcılığı da artmıştır. Aralarında Ziyâd b. Ebîh gibi gelmiş geçmiş en iyi hatiplerden olduğu belirtilen, yine onun "Betrâ" adıyla meşhur hutbesinin şaheser veya eşsiz bir hazine olarak nitelendirildiği bilinen bu isimlerin hitabetleri, onları tarihe kaydettiren en önemli özelliklerinden olmuştur.

Hitabetin hemen her devirde olduğu gibi Emevîler'de de hem iktidarın hem de muhalefetteki kişi veya grupların en güçlü silahlarından olduğu düşünüldüğünde, yönetimi ellerinde bulunduran kişilerin bu kabiliyete sahip olmasının kendileri açısından önemli artılar sağladığı muhakkaktır.

\footnotetext{
143 Taberî, Târîh, 5/335; İbnü'l- Esîr, el-Kâmîl, 3/365.

144 İbn Abdürabbih, el-ìkdül-Ferîd, 2/205.

145 Taberî, Târîh, 5/336; İbnü'l-Esîr, el-Kâmil, 3/365.

146 Câhiz, el-Beyân, 1/88.
} 


\section{Etik Beyan / Ethical Statement}

Yazar / Author
Bu çalışmanın hazırlanma sürecinde bilimsel ve etik ilkelere uyulduğu ve yararlanılan tüm çalışmaların kaynakçada belirtildiği beyan olunur/It is declared that scientific and ethical principles have been followed while carrying out and writing this study and that all the sources used have been properly cited.

Melek Yılmaz Gömbeyaz

\section{Kaynakça}

Ahmed Cevdet Paşa. Kısas-ı Enbiyâ ve Tevârîh-i Hulefâ. İstanbul: Kanaat Kütübhanesi, 1331 H. Aktaş, Ömer. “Muğîre b. Şû'be'nin Hayatı ve Kişiligŭi”. Ağrı İslamî îlimler Dergisi 2 (2018), 29-56. Ali, Cevad. el-Mufassal fi târîhi'l-Arab kable'l-İslâm. Beyrut: Dâru'l-İlm li'l-Melâyin, 1993. Apak, Âdem. İslâm Siyaset Geleneğinde Amr b. el-Âs. Ankara: Ankara Okulu Yayınları, 2001. Aycan, İrfan. "Muâviye b. Ebû Süfyân". Türkiye Diyanet Vakfi İslâm Ansiklopedisi. 30/332-334. İstanbul: TDV Yayınları, 2005.

Aycan, İrfan. Saltanata Giden Yolda Muaviye Bin Ebî Süfyan. Ankara: Ankara Okulu Yayınları, 2. Basim, 2001.

Belâzürî. Ensâbu'l-eşrâf. thk. Süheyl Zekkar - Riyaz Zirikli. 13 Cilt. Beyrut: Dâru'l-Fikr, 1996.

Belâzürî. Fütûhu'-Büldân. thk. Abdullah Enis et-Tabbâ - Ömer Enis et-Tabbâ. Beyrut: Müessesetü'l-Maârif, 1987.

Câhiz. el-Beyân ve't-Tebyîn. thk. Abdüsselam Muhammed Harun. 4 Cilt. Kahire: Dâru'l-Cîl, 1968. Dayf, Şevki. Târîhu'l-edebi'-Arabî: el-Asru'-İslâmî. Kahire: Dâru'l-Maârif, 1992.

Ebû Hanîfe ed-Dîneverî. el-Ahbâru't-tıvâl. thk. Ömer Faruk et-Tabbâ. Beyrut, ts.

Ebü'l-Fidâ. Târîhu Ebîl-Fidâ (el-Muhtasar fi ahbâri'l-beșer). thk. Mahmûd Deyyûb. 2 Cilt. Beyrut: Dârü'l-Kütübi'l-İlmiyye, 1997.

Fayda, Mustafa. Hz. Ömer Zamanında Gayr-ı Müslimler. İstanbul: MÜ IFFAV Yayınları, 1989.

Ferruh, Ömer. Târîhu'l-edebil'-Arabî. Beyrut: Dârü'l-İlm li'l-Melâyin, 4. Basım. 1981.

Hamidullah, Muhammed. İslâm Peygamberi. çev. Salih Tŭ̆. 2 Cilt. İstanbul: İrfan Yayınları, 1990. Hasson, Isaac. "Ziyād b. Abīhi". The Encyclopaedia of Islam Second Edition. 9/519-522. Leiden: Brill, 2002.

Hitti, Philip K. Siyasî ve Kültürel İslam Tarihi. çev. Salih Tuğ. 4 Cilt. İstanbul: Boğaziçi Yayınları, 1980.

İbn Abdülber en-Nemerî. el-İstîâb fì márifetill-ashâb. thk. Ali Muhammed el-Bicâvî. 4 Cilt. Kahire, Dâru Nehdati Misr, ts.

İbn Abdürabbih. el-îkdül-ferîd. thk. Abdülmecid et-Tarhînî. Beyrut, 1983.

İbn Asâkir, Ebü'l-Kâsım. Târîhu medîneti Dımaşk. 80 Cilt. thk. Muhibbüddin Ebi Said Ömer b. Garame el-Amri. Beyrut: Dâru'l-Fikr, 1995.

İbn Habîb el-Bağdâdî. Kitâbüll-Muhabber. tsh. Ilse Lichtenstadler. Beyrut: Dârü'l-Âfâki'l-Cedîde, ts. İbn Hacer el-Askalânî. el-ísâbe fi temyîzi's-sahâbe. 9 Cilt. Beyrut: Dârü'l-ìhyâi't-Türâsi'l-Arabî, ts. İbn Hallikân. Vefeyâtül'-A'yân ve enbâü ebnâi'-zamân. thk. İhsan Abbas. 8 Cilt. Beyrut: Dâru Sâdır, ts. İbn Hişam. es-Sîretü'n-Nebeviyye. thk. Mustafa es-Sakka v.dğr. 2 Cilt. Kahire: Mustafa el-Bâbî elHalebî, 1955.

İbn Kesîr, Ebü'l-Fidâ. el-Bidâye venn-nihâye. 14 Cilt. Beyrut: Mektebetü'l-Maârif - Riyad: Mektebetü'n-Nasr, ts.

İbn Kuteybe. el-Maârif. tashih Muhammed İsmail Savi. Beyrut: Dâru İhyâi't-Türâsi'l-Arabî, 2. Basim, 1970.

İbn Kuteybe. Uyûnü'l-Ahbâr. 4 Cilt. Kahire: Dârü'l-Kütübi'l-Mısriyye, 1996. 
İbn Kuteybe. el-İmâme ve's-Siyâse. thk. Taha Muhammed ez-Zeynî. 2 Cilt. Beyrut: Müessesetü'rRisâle, 1985.

İbn Manzûr. Lisânü'l-Arab. 15 Cilt. Beyrut: Dâru Sadır, ts.

İbn Sa'd.et-Tabakâtüll-kübrâ. 8 Cilt. Beyrut: Dâru Sâdır, ts.

İbn Tağrîberdî. en-Nücûmü'z-Zâhire fi Mülûki Misr ve'l-Kâhire. tkd. ve tlk. Muhammed Hüseyin Şemseddin. 16 Cilt. Beyrut: Dâru'l-Kütübi'l-ìlmiyye, ts.

İbn A‘sem el-Kûfî. el-Fütûh. thk. Ali Şî̀î. 8 Cilt. Beyrut, 1411 H.

İbnü'l-Cevzî, Ebü'l-Ferec. el-Muntazam fi târîhi'l-mülûk ve'l-ümem. thk. Muhammed Abdülkadir Atâ - Mustafa Abdülkadir Atâ. 19 Cilt. Beyrut: Dâru'l-Kütübi'l-İlmiyye, 1992.

İbnü'l-Esîr, İzzeddin. el-Kâmil fi't-târîh. 12 Cilt. Beyrut: Dâru Sâdır - Dâru Beyrût, 1965.

İbnü'l-Esîr, İzzeddin. Üsdü'l-gâbe fî márifeti's-sahâbe. 8 Cilt. Beyrut, ts.

İbnü'l-İmâd. Şezerâtüz-Zeheb fi Ahbâri Men Zeheb. thk. Abdülkadir Arnaut - Mahmûd Arnaut. Beyrut, Dâru İbn Kesîr, Ebü'l-Fidâ, 1987.

İbnü'n-Nedim. el-Fihrist. thk. Riza Teceddüd. Tahran:y.y., 1971.

Seyithanoğlu, Kenan vd. Doğuștan Günümüze Büyük İslâm Tarihi. 15 cilt. Konya: Kombassan Şirketler Topluluğu, 1994.

Köksal, Mustafa Asım. İslam Tarihi: Hazreti Muhammed (a.s.) ve İslamiyet: Medine Devri. 11 Cilt. İstanbul: Şamil Yayınevi, 1981.

Kütübî. Fevâtül'-vefeyât. thk İhsan Abbâs. 5 Cilt. Beyrut: Dâru Sadır, 1973.

Mes'ûdî, Ali b. Hüseyin. Mürûcu'z-Zeheb ve meâdinül-cevher. thk. Muhammed Muhyiddin Abdülhamid. 4 Cilt. Kahire: el-Mektebetü't-Ticareti'l-Kübra, 4. Basım, 1964.

Nüveyrî, Ahmed b. Abdülvehhâb. Nihâyetü'l-ereb fi fünûni'l-edeb. thk. Müfîd Kumeyha. 33 Cilt. Beyrut, 2004.

Önkal, Ahmet. "Dühât-1 Arab”. Türkiye Diyanet Vakfi İslâm Ansiklopedisi. 10:18-19. İstanbul: Türkiye Diyanet Vakfı Yayınları, 1994.

Önkal, Ahmet. “Amr b. Âs”. Türkiye Diyanet Vakfi İslâm Ansiklopedisi. 3/79-81. İstanbul: Türkiye Diyanet Vakfi Yayınları, 1991.

Safedî. el-Vâfi bil'-Vefeyât. thk. Ahmed el-Arnaut - Mustafa Türkî. 19 Cilt. Beyrut: Dâru İhyâi'tTürâsi'l-Arabî, 2000.

Safvet, Ahmed Zeki. Cemheratü hutabi'l-Arab fi usuri'l-Arabiyyeti'z-zâhire. Kahire: Mustafa el-Bâbî el-Halebî, 1933.

Süyûtî. Târîhu'l-Hulefâ. Kahire: el-Mektebetü't-Ticareti'l-Kübra, 4. Basım, 1969.

Taberî, Muhammed b. Cerîr. Tarihü'l-ümem ve'l-mülûk. thk. Muhammed Ebüll-Fazl İbrahim. 11 Cilt. Beyrut: Dâru Süveydân, 1970.

Ya'kûbî. Târîüül-Yakûhbî. 2 Cilt. Beyrut: Dâru Sâdır, 1960.

Yılmaz Gömbeyaz, Melek. Ziyâd b. Ebîh (Hayatt-Şahsiyeti-Devlet Adamliğı). Bursa: Uludağ Üniversitesi, Sosyal Bilimler Enstitüsü, Doktora Tezi, 2015.

Yılmaz Gömbeyaz, Melek. “Muaviye b. Ebî Süfyân'ın Muhaliflerini Bertaraf Etme Yöntemleri”. Uludağ Üniversitesi İlahiyat Fakültesi Dergisi 19/1 (2010).

Yllmaz Gömbeyaz, Melek. "Erken Dönem İslam Tarihinde Hitabetiyle Öne Çıkan Bir Siyasî: Ziyâd b. Ebîh". İhya Uluslararası İslam Araştırmaları Dergisi 6/2 (Temmuz 2020), 711-733.

Zehebî. Târîhu'l-İslâm ve vefeyâtü'l-meșâhîr ve'l-alâm. thk. Ömer Abdüsselam Tedmürî. 53 Cilt. Beyrut: Dârü'l-Kitâbi'l-Arabî, 1990.

Zehebî. Siyeru alâmi’n-nübelâ. thk. Şuayb el-Arnaut. 33 Cilt. Beyrut: Müessesetü’r-Risâle, 3. Basim, 1985.

Zirikli, Hayreddin. el-A'lâm: Kamusu terâcim. 11 Cilt. Beyrut: y.y., ts.

Zübeyrî. Nesebü Kureyş. tsh. E. Levi Provençal. Kahire: Dâru'l-Maârif, ts. 